\title{
Estimation of Some Useful Drugs in Water, Urine, and Medical Formulations Following Conventional and Modified Dispersive Microextraction Coupled with HPLC-UV
}

\author{
Mitali Sarkar*, Shanku Denrah \\ Department of Chemistry, University of Kalyani, Kalyani, India \\ E-mail: mitali_ku@yahoo.com,msarkar@klyuniv.ac.in
}

Received: 14 August 2021; Revised: 9 November 2021; Accepted: 16 November 2021

\begin{abstract}
Dispersive Liquid-Liquid Microextraction (DLLME) coupled with high-performance liquid chromatographyultraviolet spectroscopy was developed, as a fast and precise operation, for extractive recovery and estimation of two pharmaceuticals viz. moxifloxacin and galantamine, from water, urine, and medical formulations. The process was investigated for Extraction (ES) and Dispersive Solvent (DS) as well as $\mathrm{pH}$, temperature, and salt concentration. Extraction was found effective using methanol $\left(\mathrm{CH}_{3} \mathrm{OH}\right)$, as the DS, employing 1,1,2,2-tetrachloroethane $\left(\mathrm{C}_{2} \mathrm{H}_{2} \mathrm{Cl}_{4}\right)$ and chloroform $\left(\mathrm{CHCl}_{3}\right)$, as the ES, for moxifloxacin and galantamine respectively. The optimum $\mathrm{pH}$ was found to be 6.9 for moxifloxacin and 10.2 for galantamine. Temperature and salt were found to have some influence on the extraction efficiency of moxifloxacin but insignificant for galantamine. An improvement of the operation in terms of the Extraction efficiency (ER \%), Preconcentration Factor (PF), thermodynamic feasibility, and greenness were achieved during surfactant aided DLLME (SDS-DLLME), where anionic surfactant (Sodium Dodecyl Sulphate (SDS)) was employed and no DS was required. Interestingly, the volume requirement for ES was found less, compared to that in the conventional DLLME, without compromising the performance. Moreover, quantitative recovery of both the drugs was achieved using a single ES. Thus, mutual separation and simultaneous determination of moxifloxacin and galantamine may be designed. A two-phase separation with concomitant enrichment of the solute in the sediment phase occurred. The drugs in the sediment phase, on subsequent dilution with methanol, were determined using the High Performance Liquid Chromatography-Ultraviolet (HPLC-UV) system. The negative free energy changes for the operation indicated that the process was thermodynamically feasible. The process was found to be effective for the spiked recovery of the studied drugs from real samples viz, water, human urine, and commercial medical formulations.
\end{abstract}

Keywords: Dispersive Liquid-Liquid Microextraction, surfactant aided Dispersive Liquid-Liquid Microextraction, water, urine, medicine

\section{Introduction}

Pharmaceuticals or drugs are the most useful compounds in the medical treatment of humans and animals. The commonly used drugs, such as antibiotics, analgesics, anti-inflammatory, are considered pseudo persistent pollutants due to their continual input and permanent presence in the environment. ${ }^{1}$ The present report deals with recovery via

Copyright (C2021 Mitali Sarkar, et al.

DOI: https://doi.org/10.37256/sce.3120221101

This is an open-access article distributed under a CC BY license

(Creative Commons Attribution 4.0 International License)

https://creativecommons.org/licenses/by/4.0/ 
extraction of moxifloxacin and galantamine using dispersive liquid-liquid microextraction. Moxifloxacin is used for the treatment of sinusitis, bronchitis, and urinary tract infection, and galantamine is mostly used for Alzheimer's disease. However, both of them show common side effects of nausea, vomiting, diarrhea, stomach pain, heartburn, loss of appetite, etc. Moreover, it is of alarm for a healthy human if exposed to sublethal doses of such drugs from non-point sources. Thus, assessment of the contamination level, via determination, of such drugs in environmental and biological samples becomes essential. In medical formulations, the estimation of drugs is important to assess either the activity or the presence of any spurious component.

In analytical chemistry sample preparation step before detection/determination becomes very crucial, considering the solute load and matrix complexity. Generally, sample preparation protocol consists of extraction via interference removal and solute preconcentration or enrichment. Liquid-Liquid Extraction (LLE) ${ }^{2,3}$ and Solid-Phase Extraction (SPE) are widely used for certain drug analysis. ${ }^{4-6}$ Recently, solid-phase microextraction, ${ }^{7,8}$ cloud point extraction, ${ }^{9,10}$ dispersive liquid-liquid microextraction, following HPLC and Gas Chromatograph (GC) ${ }^{11,12}$ coupled with UV, fluorescence, mass spectroscopy or capillary electrophoresis, ${ }^{13-21}$ etc., are gaining attention for detection and quantification of drugs. Among the various sample preparation techniques, Dispersive Liquid-Liquid Microextraction (DLLME) is a very attractive option, as it is simple, quick, efficient, less expensive due to less solvent volume requirement and compatibility with instrumental detection system. ${ }^{22}$ The present report demonstrates Conventional DLLME (C-DLLME) and Surfactant aided DLLME (S-DLLME) for the recovery and preconcentration of moxifloxacin and galantamine in different water, urine, and medical formulations. The literature study reveals that there is only one preliminary study on DLLME of moxifloxacin while no report on DLLME of galantamine is available.

The process was investigated for different operational variables, such as nature and volume of extraction and dispersive solvent or surfactant (in case of S-DLLME), $\mathrm{pH}$, equilibration time, temperature, and ionic strength. The interference study due to common anions was also made. The feasibility as well as the performance of C-DLLME, and S-DLLME was finally compared.

\section{Material and methods}

\subsection{Reagents and materials}

Standard samples of drugs viz. moxifloxacin and galantamine, investigated in the present study, were procured from Sigma-Aldrich, India. The structure and relevant physicochemical properties of the drugs were given in Table 1. Solvents such as 1,1,2,2-tetrachloroethane $\left(\mathrm{C}_{2} \mathrm{H}_{2} \mathrm{Cl}_{4} ; 1.59 \mathrm{~g} / \mathrm{L}\right.$, ES1), chloroform $\left(\mathrm{CHCl}_{3} ; 1.49 \mathrm{~g} / \mathrm{L}\right.$, ES2), carbon tetrachloride $\left(\mathrm{CCl}_{4} ; 1.59 \mathrm{~g} / \mathrm{L}, \mathrm{ES} 3\right)$, dichloromethane $\left(\mathrm{CH}_{2} \mathrm{Cl}_{2} ; 1.33 \mathrm{~g} / \mathrm{L}, \mathrm{ES} 4\right)$, methanol $\left(\mathrm{CH}_{3} \mathrm{OH} ; 0.792 \mathrm{~g} / \mathrm{L}, \mathrm{DS} 1\right)$, ethanol $\left(\mathrm{C}_{2} \mathrm{H}_{5} \mathrm{OH}(0.789 \mathrm{~g} / \mathrm{L}, \mathrm{DS} 2)\right)$, acetonitrile $\mathrm{CH}_{3} \mathrm{CN}(0.786 \mathrm{~g} / \mathrm{L}, \mathrm{DS} 3)$ and acetone $\left(\mathrm{C}_{3} \mathrm{H}_{6} \mathrm{O} ; 0.791 \mathrm{~g} / \mathrm{L}\right.$, DS4) are of HPLC grade and were procured from Merck, India. Surfactants, such as anionic (Sodium Dodecyl Sulfate (SDS)), cationic (Cetyl Trimethyl Ammonium Bromide (CTAB)), non-ionic (polyoxyethylene 9.5 octylphenyl ether, TX100), other solvents and reagents used are of Merck, Anal R grade. Hydrochloric acid and sodium hydroxide, procured from Merck, was used to adjust the $\mathrm{pH}$ of the samples and were diluted to $0.1 \mathrm{M}$ before use. Sodium chloride ( $\mathrm{NaCl}$ ), potassium chloride $(\mathrm{KCl})$, and sodium sulfate $\left(\mathrm{Na}_{2} \mathrm{SO}_{4}\right)$ were procured from Merck, India. Milli-Q water, used in all the experiments, was produced on a Nano pure (Merck Ultrapure, India) water purification system.

\subsection{Apparatus}

Separation and determination of the drugs were carried out in an HPLC-UV system (Cecil; CE 4201). The spectral study was done using UV-Vis spectrophotometer (Shimadzu UV-2401PC) with the blank solution as the reference. A Systronics digital $\mathrm{pH}$ meter (Model no. 335) was used for $\mathrm{pH}$ measurement. The phase separation was achieved by a Rotofix centrifuge. A mixture of $\left(\mathrm{NH}_{4}\right) \mathrm{H}_{2} \mathrm{PO}_{4}$, and $\mathrm{CH}_{3} \mathrm{CN}(70: 30)$, adjusted at $\mathrm{pH} 3$ by ortho- $\mathrm{H}_{3} \mathrm{PO}_{4}$, was used as mobile phase maintaining a flow rate of $1 \mathrm{~mL} / \mathrm{min}$ in HPLC. Sample solution $\left(\mathrm{H}_{2} \mathrm{O}: \mathrm{CH}_{3} \mathrm{CN}\right.$ (50:50)) was injected into HPLC by a micro-syringe $(20 \mu \mathrm{L})$ following determination at the wavelength of 295 and $288 \mathrm{~nm}$ respectively for moxifloxacin and galantamine. 
Table 1. Structures and some physicochemical properties of the target pharmaceuticals

Analyte

\subsection{Preparation of standard and real samples}

A standard solution of $1000 \mu \mathrm{g} / \mathrm{L}$ of each drug was prepared in Milli-Q water and stored at $4{ }^{\circ} \mathrm{C}$. Working solutions, of different concentrations, were prepared by appropriate dilution of the stock.

Water samples of different origins were suitably collected and stored at $4{ }^{\circ} \mathrm{C}$. In the case of urine, an aliquot of the sample $(50 \mathrm{~mL})$ was taken from healthy male volunteers without any medication. The urine samples were treated with 2 $\mathrm{M}$ of $\mathrm{KOH}(5 \mathrm{~mL})$ to precipitate carbamide, uric acid, glucose, calcium phosphate, etc. ${ }^{23,24}$

Two commercial medical formulations viz. moxifloxacin (as liquid) and galantamine (as tablet) were taken and working solutions were prepared using the desired volume of Milli-Q water. $1 \mathrm{~mL}$ of the liquid sample in the first case and one tablet in the second case were taken for sample preparation.

The spiked samples were prepared at concentration level up to 10 and $60 \mu \mathrm{g} / \mathrm{L}$ for moxifloxacin and galantamine respectively using $1000 \mu \mathrm{g} / \mathrm{L}$ standard solution and kept at a screw cap glass test tube with a conical bottom at room temperature for about $30 \mathrm{~min}$ and filtered through a $0.45 \mu \mathrm{m}$ membrane prior to extraction.

\subsection{Extraction procedure}

In Conventional DLLME operation (C-DLLME), an aliquot of aqueous sample $(5.0 \mathrm{~mL})$ was placed in a $15 \mathrm{~mL}$ screw cap glass test tube with conical bottom. In a typical experiment, an optimum volume of DS (dispersive solvent; methanol) and ES (extraction solvent; $\mathrm{C}_{2} \mathrm{H}_{2} \mathrm{Cl}_{4}$ for moxifloxacin and $\mathrm{CHCl}_{3}$ for galantamine) was rapidly added into the sample solution, the $\mathrm{pH}$ of the solution was optimized and the mixture was gently shaken till the attainment of the equilibrium.

In the case of Surfactant aided DLLME (S-DLLME), suitable surfactant (SDS) was used instead of toxic DS. A cloudy solution was formed when the solute in the water sample was dispersed as fine droplets. The mixture was centrifuged for $4 \mathrm{~min}$ at $3000 \mathrm{rpm}$ whereby the solute was enriched in the pellet phase at the bottom. The upper phase was withdrawn by a micropipette. The sediment phase was diluted to $6 \mathrm{~mL}$ using methanol and the solute was analyzed by HPLC. 


\subsection{Extraction recovery and preconcentration factor}

Extraction performance is commonly estimated by the extraction recovery (ER \%) and Preconcentration Factor (PF). PF is defined as the ratio of the final analyte concentration in the sediment phase $\left(C_{\text {sed }}\right)$ after DLLME to the initial concentration of analyte $\left(C_{0}\right)$ in the sample solution, which is expressed as:

$$
P F=\frac{C_{\text {sed }}}{C_{0}}
$$

$C_{\text {sed }}$ was calculated from a calibration graph obtained from a direct injection of the standard solutions of drugs, of different concentrations, to a suitable ES-DS (C-DLLME) and ES-surfactant (S-DLLME) combination. ER is the percentage of total analyte amount $\left(n_{0}\right)$, which is extracted to the organic phase $\left(n_{\text {sed }}\right)$. It can be related to the PF and the phase volume ratio $\left(V_{\text {sed }} / V_{0}\right)$, and is expressed as:

$$
E R \%=\frac{n_{\text {sed }}}{n_{0}} \times 100=\frac{C_{\text {sed }}}{C_{0}} \times \frac{V_{\text {sed }}}{V_{0}} \times 100=P F \times \frac{V_{\text {sed }}}{V_{0}} \times 100
$$

where $V_{\text {sed }}$ and $V_{0}$ are the volumes of sediment and sample solution respectively.

\subsection{Method validation}

The reliability and suitability of the proposed method are assessed by the linearity, Limit of Detection (LOD), Limit of Quantification (LOQ), precision, and matrix effect. The regression coefficient $\left(\mathrm{r}^{2}\right)$ value, close to one, is used as the measure of linearity. LOD and LOQ are expressed as the ratio of signal (corresponding to analyte concentration) to noise (blank) equivalent to 3 and 10 respectively.

The precision in terms of inter-day and intra-day repeatability is expressed as the Relative Standard Deviation (RSD).

\section{Results and discussion}

Dispersive Liquid-Liquid Microextraction (DLLME) is developed as an extension of conventional Liquid-Liquid Extraction (LLE) for improved efficiency. It utilizes a pair of solvent systems viz. Extraction (ES) and Dispersive Solvent (DS) to extract solutes from the aqueous sample. The merit of DLLME is the requirement of the low volume of organic solvent, as well as the quick time of extraction. Further improvement in extraction recovery was achieved in surfactant (SDS) aided operation. The application of the proposed operation was validated for different samples of water, urine, and commercial medicine.

The efficiency of extraction is influenced by the operational variables such as nature and volume of both ES and DS or surfactant, $\mathrm{pH}$ of the sample solution, electrolyte concentration, and temperature. In order to maximize the efficiency optimization of variables constitutes the first step.

\subsection{Selection of extraction solvent in C-DLLME}

Extraction solvent plays a key role in governing the efficiency, and proper selection of ES, thus, becomes vital in Conventional DLLME (C-DLLME). The prime criteria for the selection of ES are that it must have a good affinity for the solute, lower solubility in water, be denser than water, and form an emulsion with DS. Moreover, low volatility and less toxicity of ES provide some added merit. In the present study, four different extraction solvents $(500 \mu \mathrm{L})$, such as 1,1,2,2-tetrachloroethane $\left(\mathrm{C}_{2} \mathrm{H}_{2} \mathrm{Cl}_{4} ; \mathrm{ES} 1\right)$, chloroform $\left(\mathrm{CHCl}_{3} ; \mathrm{ES} 2\right)$, carbon tetrachloride $\left(\mathrm{CCl}_{4}\right.$; ES3), dichloromethane $\left(\mathrm{CH}_{2} \mathrm{Cl}_{2} ; \mathrm{ES} 4\right)$, in presence of methanol, as the DS $(500 \mu \mathrm{L})$, was tested, at the initial solution $\mathrm{pH}$ of 4.6 for Moxifloxacin (Mox) and 6.2 for Galantamine (Gal). It was observed (Figure 1) that the extent of recovery was different 
for different combinations of ES-DS. The ER \% was found to follow an order: ES1 > ES2 > ES3 $>$ ES4 for Moxand $\mathrm{ES} 2>\mathrm{ES} 4>\mathrm{ES} 3>\mathrm{ES} 1$ for Gal. The highest recovery was obtained using $\mathrm{C}_{2} \mathrm{H}_{2} \mathrm{Cl}_{4}(\mathrm{ES} 1)$ for $\mathrm{Mox}$ and $\mathrm{CHCl}_{3}(\mathrm{ES} 2)$ for Gal. Therefore, the subsequent experiments were performed with the suitable ES-DS combination for the respective drug.

In Surfactant aided DLLME (S-DLLME) different surfactants $(500 \mu \mathrm{L})$, such as anionic (Sodium Dodecyl Sulfate (SDS)), cationic (Cetyl Trimethyl Ammonium Bromide (CTAB)), and non-ionic (polyoxyethylene 9.5 octylphenyl ether, TX-100), were tested in place of methanol. It was found that the extraction efficiency, for each drug, was higher in presence of SDS (vide section 3.5).

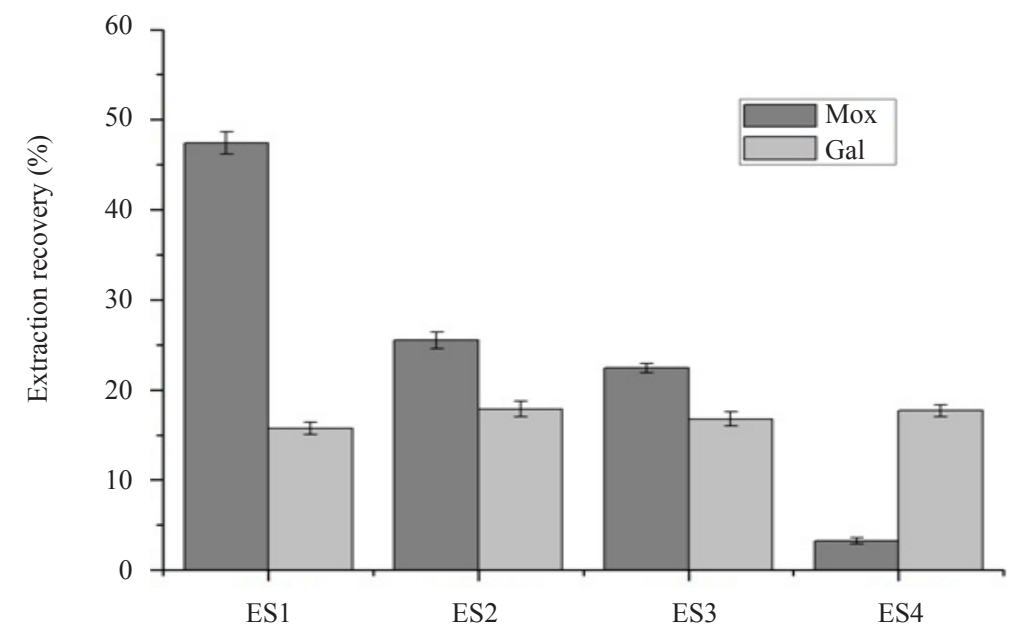

Figure 1. Selection of ES. Bar indicates standard deviations $(\mathrm{n}=3)$

Extraction condition: sample, $5 \mathrm{~mL}$; DS1, $500 \mu \mathrm{L}$; ES, $500 \mu \mathrm{L}$; solution $\mathrm{pH} 4.6$ for Mox, 6.2 for Gal; Time, $5 \mathrm{~min}$

\subsection{Optimization of the extraction solvent volume}

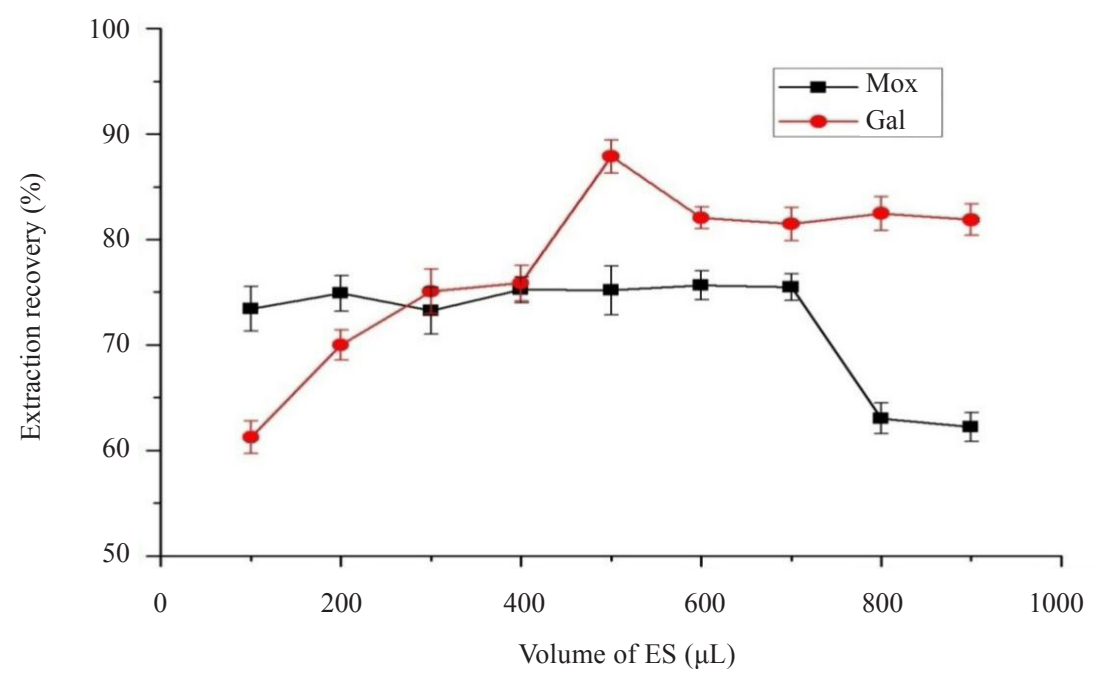

Figure 2. Optimization of ES volume; Bar indicates standard deviations $(\mathrm{n}=3)$

Extraction condition: same as that in Figure 1, except $\mathrm{pH}$, optimized at 6.9 for Mox and 10.2 for Gal

In order to investigate the role of ES volume on extraction recovery, the volume of 1,1,2,2-tetrachloroethane (ES1) 
for Mox and chloroform (ES2) for Gal was varied from 100 to $900 \mu \mathrm{L}$ (Figure 2), in presence of $500 \mu \mathrm{L}$ of methanol (DS1). The sample solution was maintained at the desired/optimized $\mathrm{pH}$ (6.9 for Mox and 10.2 for Gal), to maximize the solute recovery (vide section 3.7). It was found that extraction profiles were different for the studied solutes. The extraction recovery was found to increase smoothly for Mox with the increase of ES1volume from 100 to $700 \mu \mathrm{L}$ and decrease sharply with further volume increase. On the other hand, the extraction recovery of Gal was found to increase rapidly up to the ES2 volume of $500 \mu \mathrm{L}$ and decrease smoothly thereafter. Hence, subsequent studies were conducted with 1,1,2,2-tetrachloroethane (ES1) volume of $600 \mu \mathrm{L}$ for Mox and with chloroform (ES2) volume of $500 \mu \mathrm{L}$ for Gal.

\subsection{Selection of the dispersive solvent in C-DLLME}

Dispersive solvent has a definite role in assisting extraction, by increasing the surface area between the phases for solute mass transfer. ${ }^{25}$ The dispersive solvent is selected such that it is miscible with both the aqueous (sample) and the organic solvent (ES), enhancing dispersion of ES as droplets into the sample solution. In the present case, methanol (DS1), ethanol (DS2), acetonitrile (DS3), and acetone (DS4) were tested as the dispersive solvent, in presence of the suitable extraction solvent for each drug (vide section 3.1) and at the initial solution $\mathrm{pH}$ of 4.6 for Mox and 6.2 for Gal. It was found that the extent of recovery follows an order: DS1 $\geq$ DS2 $>>$ DS3 $>$ DS4 for Mox and DS1 > DS2 > DS3 >> DS4 for Gal. Methanol gave the highest extraction recovery (Figure 3) and was chosen as the dispersing solvent for the subsequent studies.

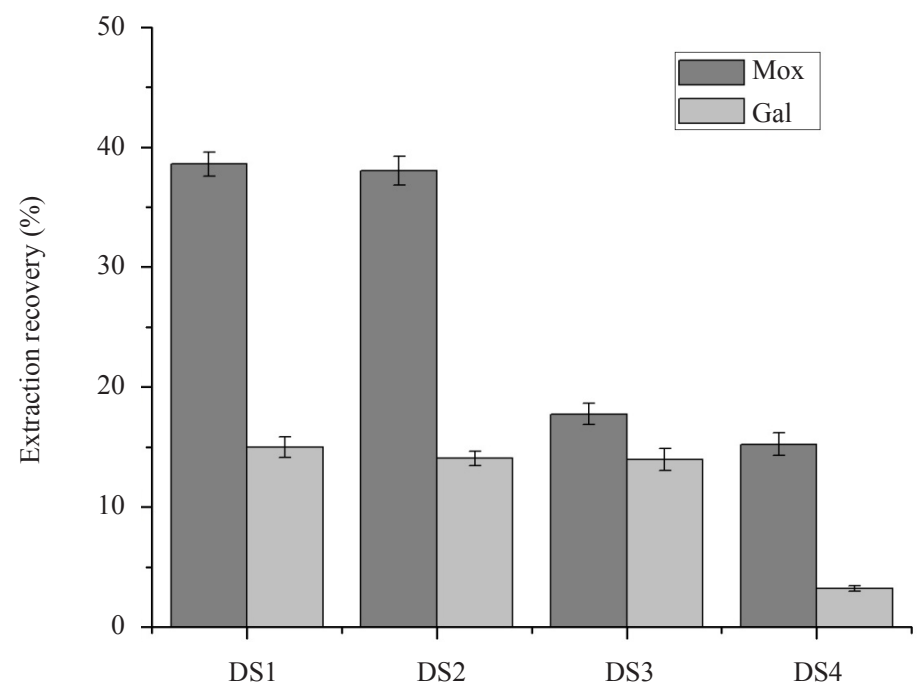

Figure 3. Selections of DS. Bar indicates standard deviations $(n=3)$

Extraction condition: same as that in Figure 1, except ES1 $600 \mu \mathrm{L}$ for Mox, and ES2 $500 \mu \mathrm{L}$ for Gal

\subsection{Optimization of methanol volume}

Optimization of DS volume was carried out varying methanol volume from 100-900 $\mu \mathrm{L}$, in presence of the suitable ES for each drug, maintaining the sample solution at the desired pH of 6.9 for Mox and 10.2 for Gal (vide section 3.7). The effect of DS volume on extraction recovery was shown in Figure 4. In the case of Mox, with increasing DS volume from 100 to $200 \mu \mathrm{L}$ the percentage recovery was found to increase gradually and decrease thereafter. However, for Gal percentage recovery was found to increase up to $300 \mu \mathrm{L}$ and gradual decrease thereafter. In presence of insufficient methanol, the extraction solvent could not disperse in water completely effecting poor extraction. Beyond the optimum volume of methanol, the decrease was due to the dilution effect. In the present case, 200 and $300 \mu \mathrm{L}$ of methanol were found as the optimum volume of DS for Mox and Gal respectively. 


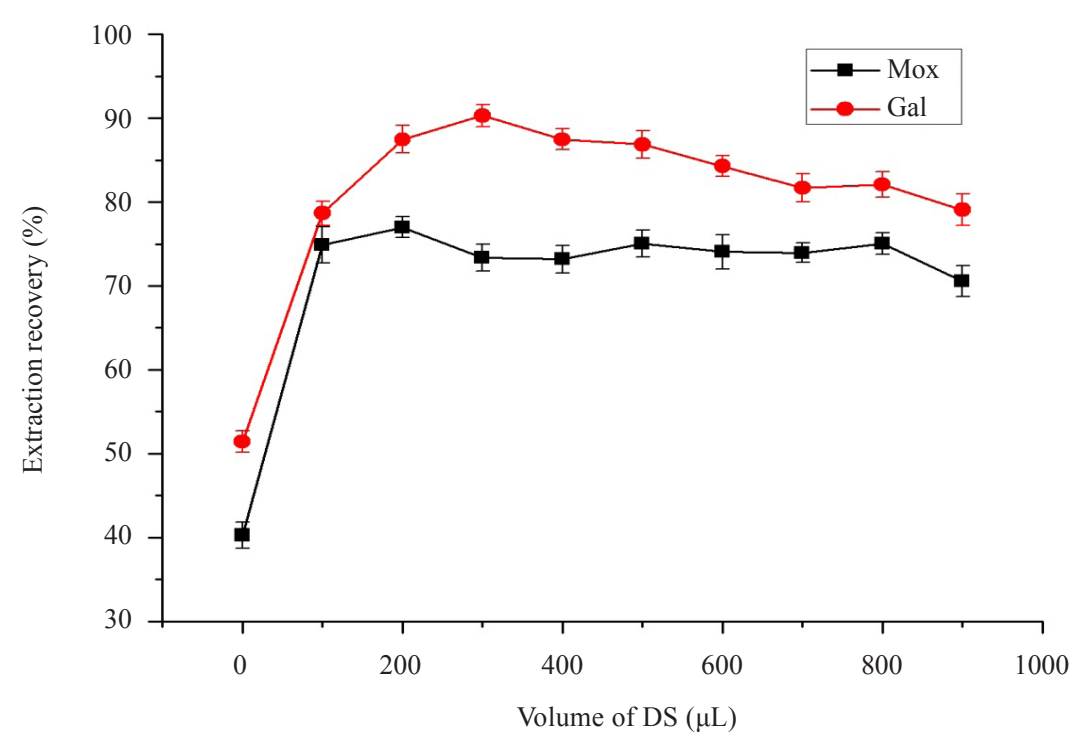

Figure 4. Optimization of the DS volume. Bar indicates standard deviations $(n=3)$ Extraction condition: same as that in Figure 3, except pH optimized at 6.9 for Mox, 10.2 for Gal

\subsection{Selection of surfactant for SAE (S-DLLME)}

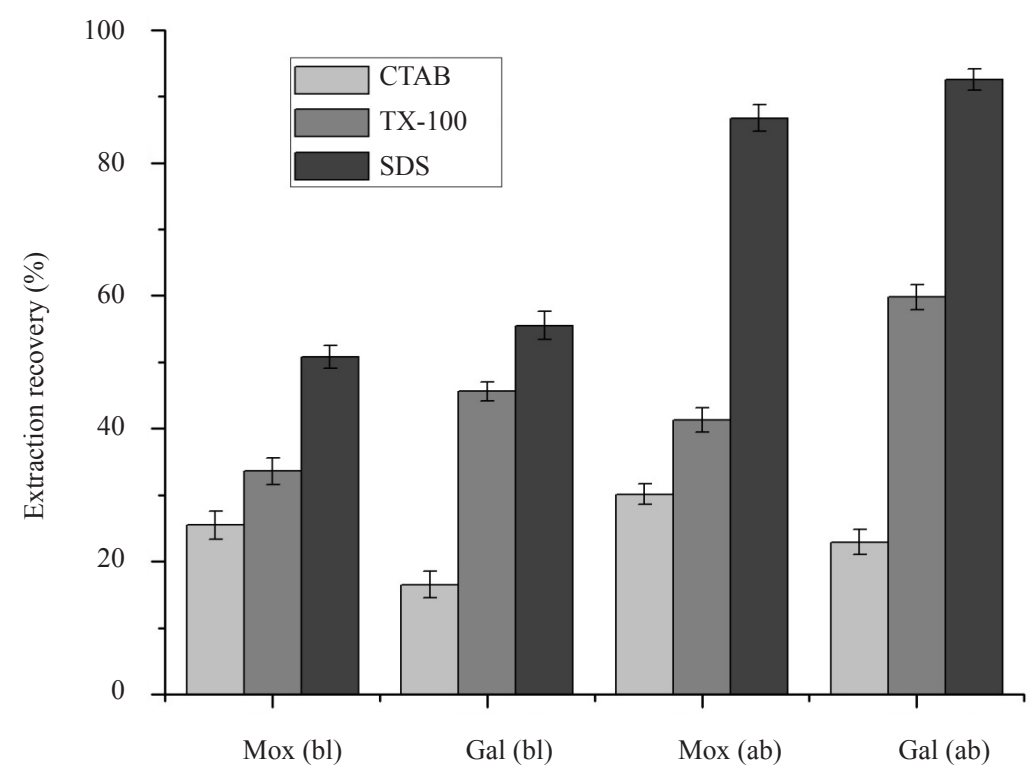

Figure 5. Selection of surfactant: $\mathrm{bl}=$ below $\mathrm{CMC}, \mathrm{ab}=$ above CMC; Bar indicates standard deviations $(\mathrm{n}=3)$ Extraction condition: sample volume, $5 \mathrm{~mL}$; SDS, $500 \mu \mathrm{L}$; ES, $100 \mu \mathrm{L}, \mathrm{pH} 4.6$ for Mox, 6.2 for Gal; Time, $5 \mathrm{~min}$

C-DLLME, was though found efficient in terms of efficiency and Preconcentration Factor (PF), it utilizes some volume of DS. In order to improve the operation, in the context of safer route development, surfactant in place of DS was tested. All the three kinds of surfactants $(500 \mu \mathrm{L})$, viz. cationic (Cetyl Trimethyl Ammonium Bromide (CTAB)), anionic (Sodium Dodecyl Sulfate (SDS)), and neutral (Triton X-100; TX-100), both below and above their Critical Micellar Concentrations (CMC), were employed, keeping the respective ES (100 $\mu \mathrm{L}$, each) i.e., ES1 for Mox and ES2 for Gal, at the initial solution $\mathrm{pH}$ of 4.6 and 6.2 respectively. It was found that in the case of CTAB the extraction 
recovery of both the drugs was less compared to the respective ES-DS combination, due to additional electrostatic repulsion between the cationic drugs and the cationic surfactant. In the case of TX-100 the extraction recovery of both the drugs was comparatively higher than in presence of CTAB, but still less compared to the respective ES-DS combination, at the optimized condition. The presence of non-ionic surfactant may impart micelle formation and solute dispersion. On the other hand, the extraction recovery of both the drugs was improved much in presence of SDS, due to electrostatic attraction between the cationic drugs and the anionic surfactant. The effect of SDS above CMC $\left(7.5 .10^{-3} \mathrm{M}\right)$ was much pronounced compared to that below CMC $\left(5.0 .10^{-3} \mathrm{M}\right)$. It may be assumed that SDS forms an effective micellar core to entrap the drug molecules resulting in improvement of both in ER \% and Preconcentration Factor (PF) for each drug (Figure 5). Thus, SDS was selected, as the suitable surfactant, for S-DLLME operation.

\subsection{Optimization of SDS volume in S-DLLME}

In order to optimize the volume of SDS (> CMC), the study was carried out varying SDS from 100 to $900 \mu \mathrm{L}$, in the initial solution $\mathrm{pH}$ of 4.6 for Mox and 6.2 for Gal, employing $100 \mu \mathrm{L}$ of the respective ES (Figure 6). The results indicated that maximum extraction recovery of 87.2 and $92.5 \%$ for Mox and Gal respectively occurred with 500 and 300 $\mu \mathrm{L}$ of SDS. The PF value was simultaneously enhanced for each drug. Interestingly, the volume requirement of the ES in S-DLLME was found less compared to that in C-DLLME. Moreover, the $\mathrm{pH}$ adjustment of the analyte solution was not required. Quantitative recovery was observed with a combination of ES1 $(100 \mu \mathrm{L})$-SDS $\left(7.5 .10^{-3} \mathrm{M}, 500 \mu \mathrm{L}\right)$ for Mox $(89 \%)$, and a combination of ES2 $(100 \mu \mathrm{L})$-SDS $\left(7.5 .10^{-3} \mathrm{M}, 300 \mu \mathrm{L}\right)$ for Gal $(93 \%)$ in S-DLLME, in contrast to the combination of ES1 $(200 \mu \mathrm{L})$-DS1 $(200 \mu \mathrm{L})$ for Mox $(77 \%)$ and ES2 $(500 \mu \mathrm{L})$-DS1 $(300 \mu \mathrm{L})$ for Gal $(90.3 \%)$ at the optimized $\mathrm{pH}$ in C-DLLME. Thus, more greenness in extraction was achieved with S-DLLME, due to the requirement of the lesser volume of ES and no DS.

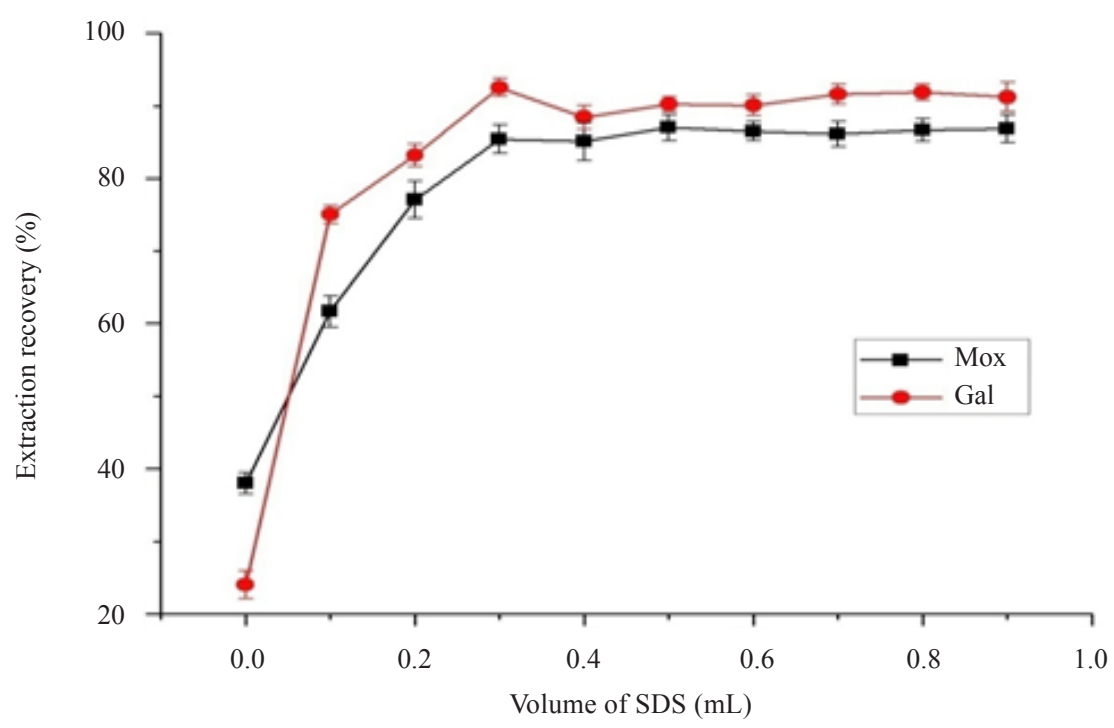

Figure 6. Optimization of SDS volume. Bar indicates standard deviations $(n=3)$ Extraction condition: same as that in Figure 5

Further, the experiment was carried to investigate the possibility of mutual separation of the studied drugs using a single combination of binary solvent (ES-surfactant) mixture. Figure 7 illustrated that in presence of SDS either ES1 or ES2 may effectively recover $(>80 \%)$ both the drugs. However, the extent of recovery was found more with ES1-SDS (89.6\% for Mox and $92.1 \%$ for Gal) than ES2-SDS (81.8\% for Mox and $85.2 \%$ for Gal). The main advantage of SDS assisted extraction was that the requirement of ES volume was less compared to that in conventional DLLME. Thus, with a combination of ES1-SDS, about $90 \%$ of both drugs were extracted. 


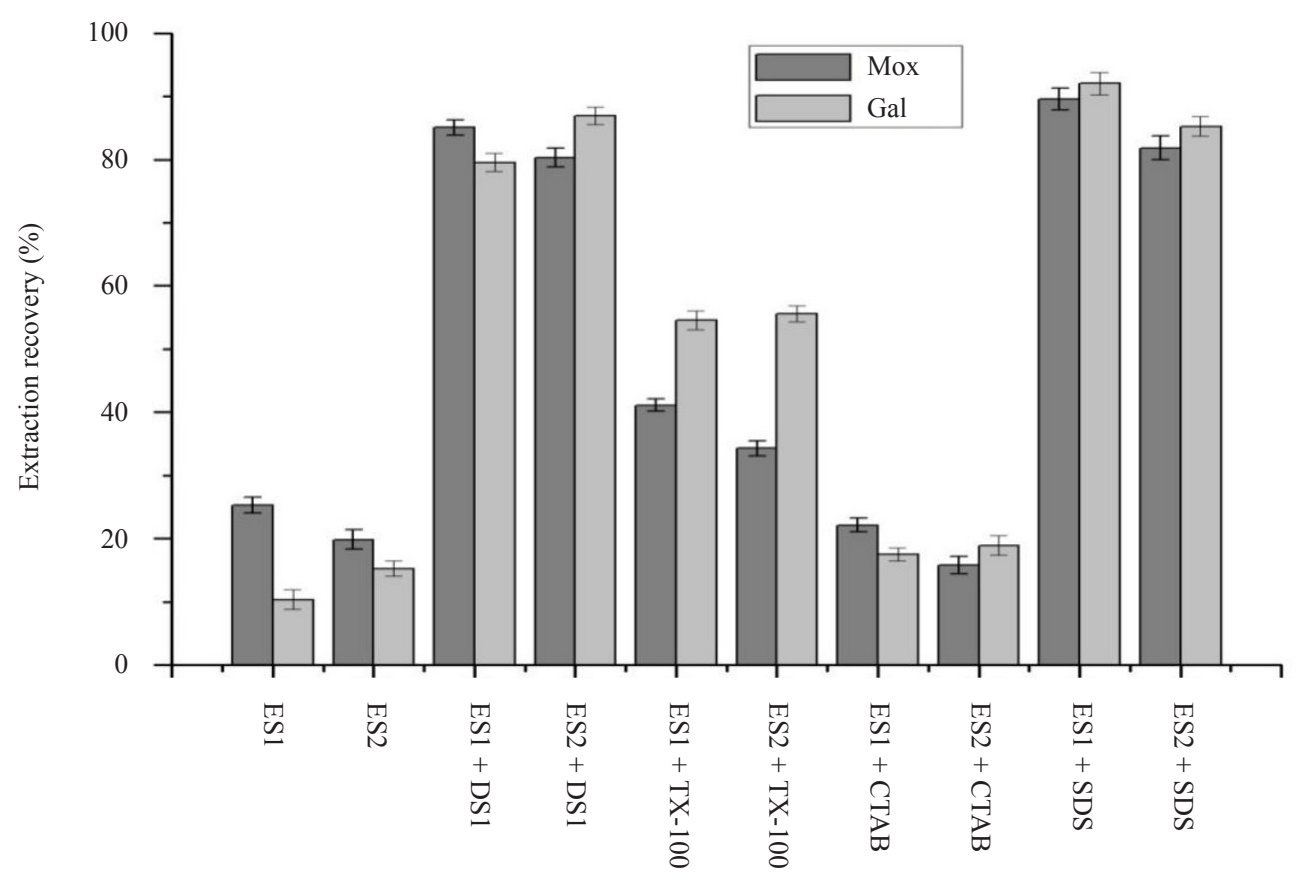

Figure 7. Extraction performances in different solvent systems. Bar indicates standard deviations $(\mathrm{n}=3)$

\subsection{Effect of $p H$}

$\mathrm{pH}$-dependent solubility and stability of the drug truly govern the transfer of target analyte from aqueous to organic phase in liquid-phase microextraction. Due to the acid-base property of the drug, ionization occurs with the change of solution $\mathrm{pH}$ and hence $\mathrm{pH}$ has a direct influence on the extraction. The unionized species is more likely to be extracted into the extraction solvent than the ionized form. ${ }^{26}$ It was found that for both the drug's extraction increased with the increase of $\mathrm{pH}$. The highest extraction was found to occur at $\mathrm{pH} 6.9$ and 10.2 for Mox and Gal respectively, in conventional DLLME (Figure 8). The $\mathrm{pH}$-dependent extraction behavior may be assessed from the dissociation constant $\left(\mathrm{pK}_{\mathrm{a}}\right)$ of the drugs. Moxifloxacin contains one basic amine group $\left(-\mathrm{NH}_{2}\right)$ and one acidic group (-COOH) that corresponds to two $\mathrm{pK}_{\mathrm{a}}\left(\mathrm{pK}_{\mathrm{a} 1}\right.$ and $\left.\mathrm{pK}_{\mathrm{a} 2}\right)$ values. Moxifloxacin tends to exist as the cation at $\mathrm{pH}$ below $\mathrm{pK}_{\mathrm{a} 1}$ of 5.69. An increase of $\mathrm{pH}$ above this would increase the portion of Mox to exist as the neutral molecule. However, the further increase of $\mathrm{pH}$ above $\mathrm{pK}_{\mathrm{a} 2}$ of 9.42 would change the neutral species to the anionic form. So, Mox is expected to be extracted more efficiently between $\mathrm{pH} 5.69$ to $9.42 .{ }^{27}$ Similarly, the greater extraction efficiency of Gal at a $\mathrm{pH}$ of 10.2 may be explained by its $\mathrm{pK}_{\mathrm{a}}$ value (8.2). It is expected that $\mathrm{Gal}$ exists as neutral species and is extracted above a $\mathrm{pH}$ value of its $\mathrm{pK}_{\mathrm{a}}$.

The extraction recovery was found to be higher at the initial solution $\mathrm{pH}$ of 4.6 for Mox (86.7\%) and at the initial solution $\mathrm{pH}$ of 6.2 for Gal (92.5\%) in S-DLLME employing SDS concentration higher than CMC (Figure 5), compared to those in C-DLLME at optimized pH condition of 6.9 for Mox and 10.2 for Gal (77\% for Mox and $90.3 \%$ for Gal, Figure 4). However, below CMC the extent of extraction was found to be less $(50.8 \%$ for Mox and $55.5 \%$ for Gal, Figure 5), compared to those of C-DLLME (Figure 4). Therefore, the pH-dependent extraction behavior of the drugs, using $800 \mu \mathrm{L}$ of SDS below $\mathrm{CMC}\left(5 \cdot 0.10^{-3} \mathrm{M}\right)$, was further investigated (Figure 9).

Moxifloxacin extraction showed an almost linear and gradual increase up to a $\mathrm{pH}$ increase of 6.5 with a slight gradual decrease beyond it. The highest recovery of $88.6 \%$ was observed between $\mathrm{pH}$ of 6.5 to 7.3 . The extraction behavior of galantamine with the change of solution $\mathrm{pH}$ showed a different trend. While $94 \%$ recovery occurred at $\mathrm{pH}$ 9.0 almost $80 \%$ recovery was observed at $\mathrm{pH}$ 7.6. The change in the extraction behavior of the drugs for S-DLLME compared to that of the C-DLLME may be due to the acid/base interaction of SDS influencing the micellar core structure formation. ${ }^{28}$ In S-DLLME, below CMC of SDS, at least $80 \%$ recovery of the drugs at neutral solution $\mathrm{pH}$ condition was observed particularly for real sample analysis. 


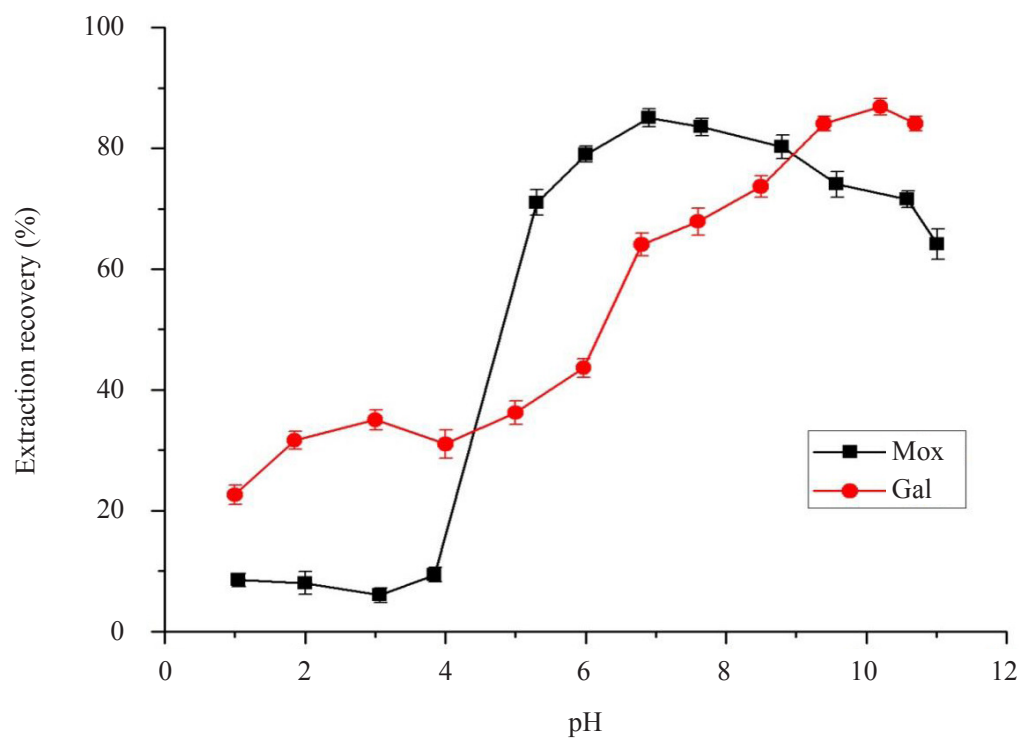

Figure 8. Effect of $\mathrm{pH}$ on C-DLLME. Bar indicates standard deviations $(\mathrm{n}=3)$

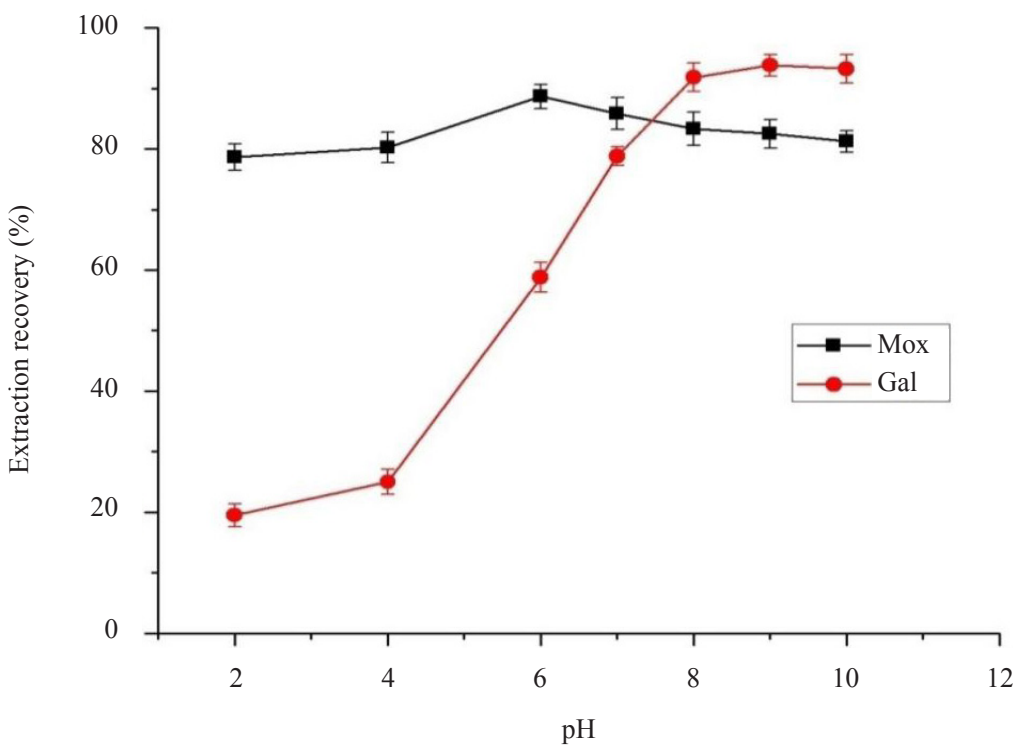

Figure 9. Effect of $\mathrm{pH}$ on S-DLLME. Bar indicates standard deviations $(\mathrm{n}=3)$ Extraction condition: same as that in Figure 5, except SDS $(<\mathrm{CMC}, 800 \mu \mathrm{L})$

\subsection{Effect of extraction time}

During DLLME, when ES is dispersed into the aqueous phase it transforms into fine droplets and phase separation is done by shaking and centrifugation. Such mechanical operation assists to reach the equilibrium via mass transfer that constitutes the limiting step of extraction. The fine droplets could extract analyte rapidly owing to shorter diffusion distance and large specific surface area. ${ }^{29}$ The extraction profile in conventional and SDS aided DLLME was shown in Figure 10 and Figure 11 for Mox and Gal respectively. The equilibrium was reached essentially within 4 min for both the drugs in both C-DLLME and S-DLLME (SDS > CMC). However, the ER \% of the drugs was found to be higher in the S-DLLME than in the C-DLLME. 


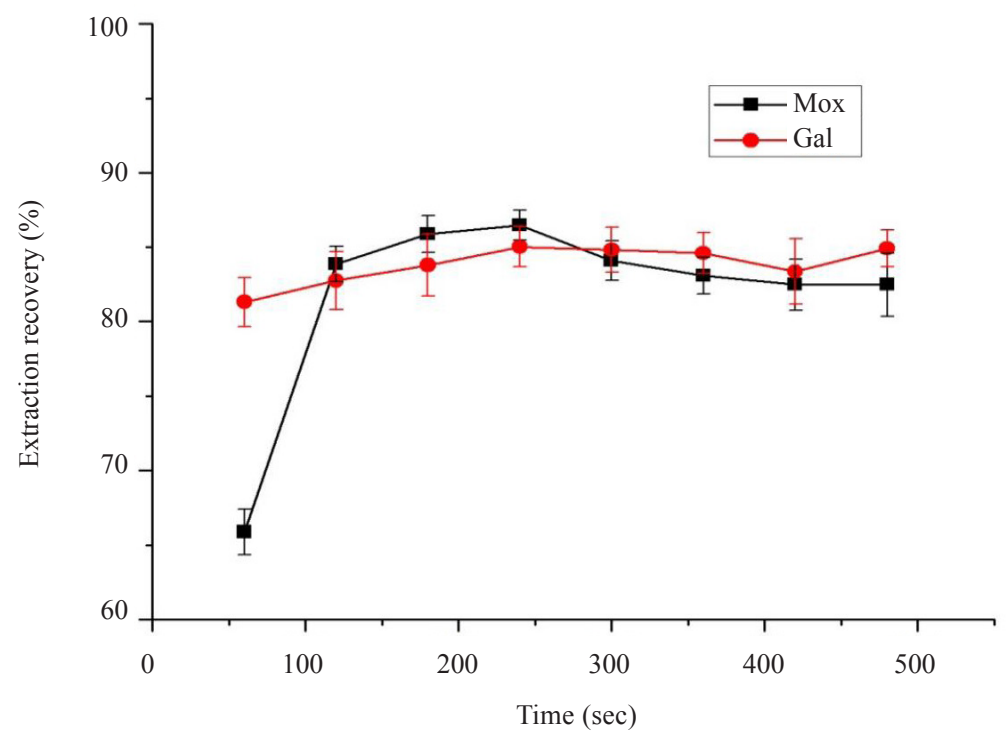

Figure 10. Effect of extraction time on C-DLLME. Bar indicates standard deviations $(\mathrm{n}=3)$ Extraction condition: same as that in Figure 8, except $\mathrm{pH}, 6.9$ for Mox and 10.2 for Gal

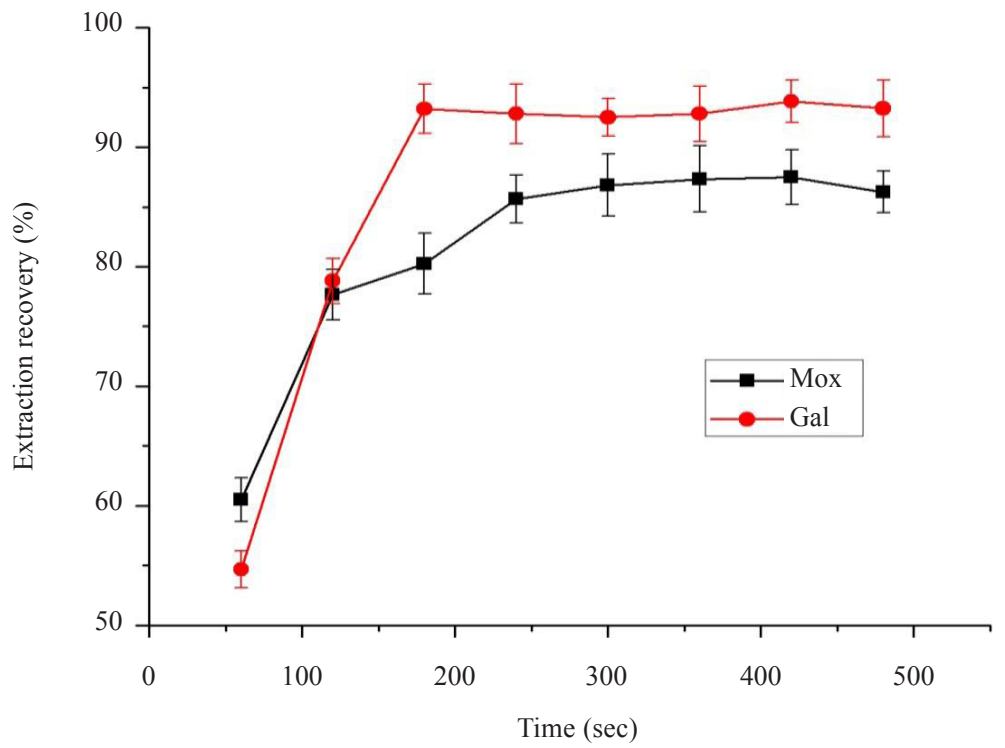

Figure 11. Effect of extraction time on S-DLLME. Bar indicates standard deviations $(\mathrm{n}=3)$ Extraction condition: same as that in Figure 9, except SDS (>CMC, $100 \mu \mathrm{L})$

\subsection{Effect of temperature}

The temperature may govern the extraction either by modifying the mass transfer rate of the analyte and/or changing the partition equilibrium between the phases. In order to examine the effect of temperature on DLLME, both C-DLLME and S-DLLME aided the experiments were carried out without optimizing the volume of ES, DS, or the surfactant and the solution $\mathrm{pH}$, varying the temperature from 10 to $70{ }^{\circ} \mathrm{C}$. The results indicated that in the case of C-DLLME there was no significant effect for Gal. A maximum recovery of $44.3 \%$ was observed at around $40{ }^{\circ} \mathrm{C}$ for Mox (Figure 12), although, less than that at the optimized $\mathrm{pH}$ condition. However, S-DLLME remained unaffected by the change of operational temperature. A maximum recovery of 87 and $93 \%$ for Mox and Gal respectively was observed at the room temperature and optimized ES1-SDS combination. 


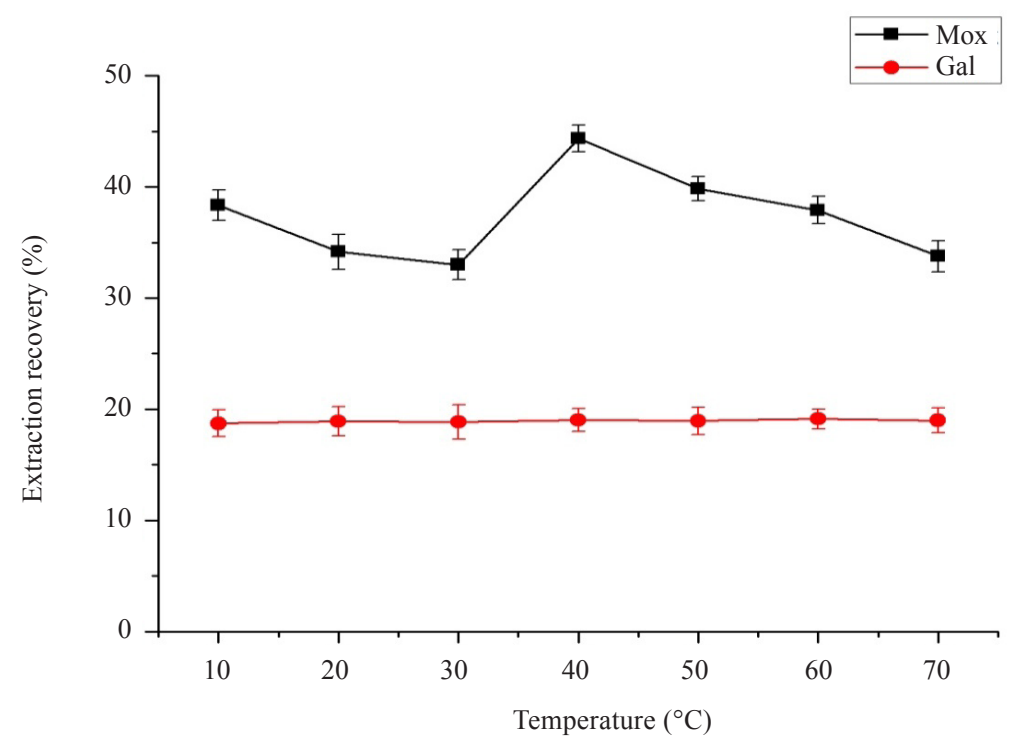

Figure 12. Effect of temperature. Bar indicates standard deviations $(\mathrm{n}=3)$

\subsection{Effect of salt}

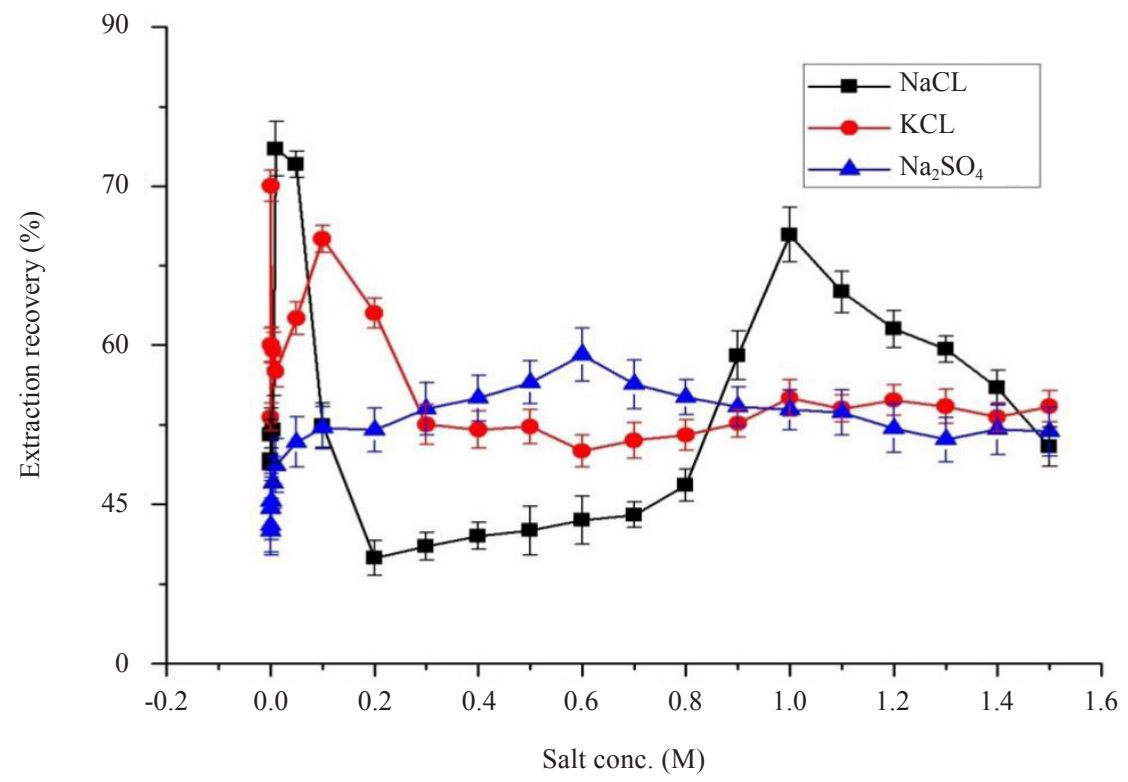

Figure 13. Effect of salt for Mox. Bar indicates standard deviations $(\mathrm{n}=3)$

It is found that the addition of salt increases the DLLME performance similarly as in the conventional liquid-liquid extraction. When the salt is added, the transfer of analyte into the organic phase increased due to the lesser availability of free water in the aqueous phase. ${ }^{30}$ Initially, $\mathrm{NaCl}$ and $\mathrm{KCl}(0-1.5 \mathrm{M})$ were added to the sample solution, and recovery of Gal remained essentially unaltered but a significant effect was observed on the recovery of Mox. The experiment was carried out for the experiment condition of Figure 1 for C-DLLME without optimizing the volume of ES, DS, and the pH. Higher recovery of Mox (79\% and 70\% respectively) at two concentration regions viz. low [0.03-0.08 (M)] and high [1.05-1.15 (M)] was found (Figure 13). The increased recovery at the low $\mathrm{NaCl}$ concentration region may be 
due to the common ion $\left(\mathrm{Cl}^{-}\right)$effect as moxifloxacin hydrochloride was taken as the analyte. Again, in the high $\mathrm{NaCl}$ concentration region, the salting-out effect may become pronounced. A similar effect on Mox recovery was observed with $\mathrm{KCl}(0-1.5 \mathrm{M})$ addition. The extent of extraction was found to be $76 \%$ at lower $\mathrm{KCl}$ concentration $(0.05 \mathrm{M})$ and $70 \%$ at higher $\mathrm{KCl}$ concentration of $(1.0 \mathrm{M})$. However, observed high recovery $(60 \%)$ in presence of $\mathrm{Na}_{2} \mathrm{SO}_{4}(0.7 \mathrm{M})$ may be due to the salting-out effect (Figure 13). A similar study of the salt addition on S-DLLME, reflected insignificant effects on ER \% and PF for both the drugs. This is probably because of the high enrichment influence of the micellar core of SDS for the analytes.

\subsection{Thermodynamic feasibility}

The feasibility of any chemical interaction is governed by Gibbs standard free energy change $\left(\Delta G^{0}\right)$. At any point in time, a negative $\Delta G^{0}$ indicates the feasible pathway. In the present case of extraction free energy change was calculated from the Gibbs-Helmholtz equation as:

$$
\Delta G^{0}=-R T \ln K_{c}
$$

where $R$ is the universal gas constant $(\mathrm{J} / \mathrm{mol} / \mathrm{K}), T$ is the absolute temperature $(\mathrm{K})$ and $K_{c}$ is the equilibrium constant, which can be calculated from the ratio of equilibrium analyte concentration in sediment phase to that of the aqueous phase.

$\Delta G^{0}$ values are found to be -8.33 and $-6.30 \mathrm{~kJ} / \mathrm{mole}$ for Mox and Gal respectively for C-DLLME. The negative values indicate that extraction is thermodynamically feasible. In the case of S-DLLME $-\Delta G^{0}$ value increases for both the drugs. In the case of Mox, $-\Delta G^{0}$ was found to increase from 8.33 to $9.36 \mathrm{~kJ} / \mathrm{mole}$ and 6.30 to $9.37 \mathrm{~kJ} / \mathrm{mole}$ for Gal. The higher $-\Delta G^{0}$ value compared to C-DLLME indicates a more favorable extraction in S-DLLME for the drugs.

\subsection{Quantitative analysis}

The Calibration curve for each drug was found linear under the optimized condition. The validity testing was done using the parameters viz. the correlation of linear determination $\left(\mathrm{r}^{2}\right)$, the Limit of Detection (LOD), and the Limit of Quantification (LOQ) (Table 2). The values were found almost similar for C-DLLME, and S-DLLME. Svinyarov et al. ${ }^{31}$ and Lopez et al. ${ }^{32}$ reported the LOD for Gal of 0.5 and $0.6 \mu \mathrm{g} \mathrm{mL}^{-1}$ respectively during solid-phase extraction. In the case of Mox, Herrera-Herrera et al. ${ }^{33}$ found the LOD values of 3.47, 1.3, and $1.07 \mu \mathrm{g} \mathrm{L}^{-1}$ for water, mineral water, and runoff water respectively after DLLME. Szultka et al. ${ }^{34}$ using HPLC-UV and LC-MS/MS after SPE reported the LOD values of 0.041 and $0.139 \mu \mathrm{g} \mathrm{mL}^{-1}$ respectively for Mox. The present study shows improved LOD compared to the reported methods. The $\mathrm{r}^{2}$ values are found to be $>0.995$ in all the studied samples except for urine. A somewhat lower value of $r^{2}$ for urine may be due to the matrix composition. The matrix effect has little influence on the samples of water and drug.

The optimum extraction condition for Mox was found to be, ES1 $(600 \mu \mathrm{L})$-DS1 $(200 \mu \mathrm{L})$, with 4 min of extraction time at the optimized $\mathrm{pH}$ of 6.9 in C-DLLME, and ES1 $(100 \mu \mathrm{L})$-SDS $\left(7.5 .10^{-3} \mathrm{M}, 500 \mu \mathrm{L}\right)$, with 4 min of extraction at initial solution $\mathrm{pH}$ of 4.6 in S-DLLME. In both cases, recoveries were found greater than $85 \%$ and the LODs ranged from 0.9 to $1.0 \mu \mathrm{g} / \mathrm{L}$. On the other hand, the optimum extraction condition for Gal was found to be, ES2 (500 $\mu \mathrm{L})$-DS1 $(300 \mu \mathrm{L})$ with 4 min of extraction time at the optimized $\mathrm{pH}$ of 10.2 in C-DLLME, and ES1 (100 $\mu \mathrm{L})$-SDS (7.5.10 $0^{-3} \mathrm{M}$, $300 \mu \mathrm{L}$ ) with 4 min of extraction time at initial solution $\mathrm{pH}$ of 6.2 in S-DLLME. In both cases, recoveries greater than $90 \%$ were obtained and LODs ranged from 4.25 to $5.0 \mu \mathrm{g} / \mathrm{L}$.

The acceptability of the process was indicated by precision and accuracy. The precision and accuracy of the method were assessed under the optimized conditions for both intra and inter-days. While the precision expresses the closeness of the successive measurements of an analyte, the accuracy estimates the deviation of mean result from the individual concentration. The Quality Control (QC) samples were prepared at low, medium, and high concentrations of 2.5, 5, and $10 \mu \mathrm{g} / \mathrm{L}$ for Mox and 10,30, and $50 \mu \mathrm{g} / \mathrm{L}$ for Gal and analyzed on the same day (intra-day assay) and three different days (inter-day assay). Calculations were based on three replicates (intra-day and inter-day) of QC samples. The obtained results were expressed as the Relative Standard Deviation (RSD) and the Relative Error (RE). 
The obtained results were presented in Table 3 and Table 4 for Mox and Gal respectively. The relative error was found to be in between 7.6 and $39.8 \%$ for C-DLLME and 8.0 and $15.2 \%$ for S-DLLME in the case of Mox; and the case of Gal in between 9.1 and $20.7 \%$ for C-DLLME and 2.9 and $16.6 \%$ for S-DLLME. In C-DLLME, RSD was found to be range from 0.80-1.51 for Mox and from 1.21-1.59 for Gal. In S-DLLME, RSD was found to be range from 0.481.39 for Mox and from 0.58-1.14 for Gal (Table 3, 4). Thus, S-DLLME was found to be more precise and accurate than C-DLLME. The results demonstrated that the values were within the acceptable range recommended by the Food and Drug Administration (FDA).

Table 2. Analytical performance of C-DLLME and S-DLLME

\begin{tabular}{|c|c|c|c|c|c|}
\hline \multirow{2}{*}{ Parameter } & \multirow{2}{*}{ Sample } & \multicolumn{2}{|c|}{ C-DLLME } & \multicolumn{2}{|c|}{ S-DLLME } \\
\hline & & Moxifloxacin & Galantamine & Moxifloxacin & Galantamine \\
\hline \multirow[t]{7}{*}{$\begin{array}{c}\text { Linear equation } \\
\text { of the calibration; } \\
\mathrm{r}^{2}\end{array}$} & Mineral water & $\begin{array}{c}\mathrm{y}=0.852 \mathrm{x}+0.073 \\
0.998\end{array}$ & $\begin{array}{c}\mathrm{y}=0.863 \mathrm{x}+0.126 \\
0.999\end{array}$ & $\begin{array}{c}\mathrm{y}=0.873 \mathrm{x}+0.150 \\
0.999\end{array}$ & $\begin{array}{c}y=0.906 x+0.093 \\
0.999\end{array}$ \\
\hline & Tap water & $\begin{array}{c}y=0.818 x+0.134 \\
0.995\end{array}$ & $\begin{array}{c}\mathrm{y}=0.880 \mathrm{x}+0.464 \\
0.998\end{array}$ & $\begin{array}{c}y=0.832 x+0.302 \\
0.996\end{array}$ & $\begin{array}{c}y=0.879 x-0.026 \\
0.993\end{array}$ \\
\hline & River water & $\begin{array}{c}y=0.805 x+0.200 \\
0.997\end{array}$ & $\begin{array}{c}\mathrm{y}=0.841 \mathrm{x}-1.086 \\
0.995\end{array}$ & $\begin{array}{c}y=0.829 x+0.286 \\
0.991\end{array}$ & $\begin{array}{c}y=0.896 x-0.497 \\
0.995\end{array}$ \\
\hline & Rain water & $\begin{array}{c}y=0.820 x+0.184 \\
0.996\end{array}$ & $\begin{array}{c}y=0.868 x-0.254 \\
0.997\end{array}$ & $\begin{array}{c}y=0.819 x+0.308 \\
0.990\end{array}$ & $y=0.862 x-0.913$ \\
\hline & Urine & $\begin{array}{c}y=0.626 x+0.112 \\
0.977\end{array}$ & $\begin{array}{c}y=0.899 x-0.578 \\
0.981\end{array}$ & $\begin{array}{c}\mathrm{y}=0.711 \mathrm{x}+0.817 \\
0.974\end{array}$ & $\begin{array}{c}\mathrm{y}=1.024 \mathrm{x}-2.419 \\
0.978\end{array}$ \\
\hline & Medicine 1 & $\begin{array}{c}y=0.834 x+0.046 \\
0.995\end{array}$ & - & $\begin{array}{c}\mathrm{y}=0.810 \mathrm{x}+0.347 \\
0.991\end{array}$ & - \\
\hline & Medicine 2 & - & $\begin{array}{c}\mathrm{y}=0.871 \mathrm{x}-0.024 \\
0.995\end{array}$ & - & $\begin{array}{c}y=0.896 x-0.390 \\
0.997\end{array}$ \\
\hline \multirow[t]{7}{*}{$\mathrm{LOD}(\mu \mathrm{g} / \mathrm{L})$} & Mineral water & 1.00 & 5.00 & 0.90 & 4.25 \\
\hline & Tap water & 1.25 & 4.25 & 1.00 & 4.00 \\
\hline & River water & 1.42 & 5.50 & 1.25 & 4.75 \\
\hline & Rain water & 1.30 & 5.00 & 1.30 & 4.50 \\
\hline & Urine & 2.01 & 4.00 & 1.75 & 4.00 \\
\hline & Medicine 1 & 0.95 & - & 0.90 & - \\
\hline & Medicine 2 & - & 5.25 & - & 4.50 \\
\hline \multirow[t]{7}{*}{$\mathrm{LOQ}(\mu \mathrm{g} / \mathrm{L})$} & Mineral water & 2.50 & 10.00 & 2.50 & 8.00 \\
\hline & Tap water & 2.75 & 9.50 & 2.50 & 8.50 \\
\hline & River water & 2.50 & 10.50 & 2.25 & 9.00 \\
\hline & Rain water & 2.40 & 9.00 & 2.50 & 9.00 \\
\hline & Urine & 2.75 & 9.00 & 2.35 & 8.50 \\
\hline & Medicine 1 & 2.10 & - & 2.00 & - \\
\hline & Medicine 2 & - & 8.50 & - & 8.50 \\
\hline
\end{tabular}

y: detector response (chromatographic peak area), $\mathrm{x}$ : concentration 
Table 3. Analytical precision and accuracy of C-DLLME and S-DLLME for Mox

\begin{tabular}{|c|c|c|c|c|c|}
\hline \multirow{2}{*}{ Sample } & \multirow{2}{*}{$\begin{array}{l}\text { Added } \\
(\mu \mathrm{g} / \mathrm{L})\end{array}$} & \multicolumn{2}{|c|}{$\begin{array}{c}\text { C-DLLME } \\
\text { Found mean } \pm \text { SD; RSD } \% ; \text { RE } \%\end{array}$} & \multicolumn{2}{|c|}{$\begin{array}{l}\text { S-DLLME } \\
\text { Found mean } \pm \text { SD; RSD } \% ; \text { RE } \%\end{array}$} \\
\hline & & Inter day & Intra day & Inter day & Intra day \\
\hline \multirow[t]{3}{*}{ Mineral water } & 2.5 & $\begin{array}{c}2.10 \pm 0.02 \\
1.25 \\
16.0\end{array}$ & $\begin{array}{c}2.12 \pm 0.02 \\
1.14 \\
15.2\end{array}$ & $\begin{array}{c}2.21 \pm 1.25 \\
0.93 \\
11.6\end{array}$ & $\begin{array}{c}2.22 \pm 1.1 \\
0.97 \\
11.2\end{array}$ \\
\hline & 5.0 & $\begin{array}{c}4.40 \pm 0.06 \\
1.44 \\
12.0\end{array}$ & $\begin{array}{c}4.30 \pm 0.05 \\
1.34 \\
14.0\end{array}$ & $\begin{array}{c}4.52 \pm 1.38 \\
0.61 \\
9.6\end{array}$ & $\begin{array}{c}4.43 \pm 1.24 \\
0.82 \\
11.4\end{array}$ \\
\hline & 10.0 & $\begin{array}{c}8.52 \pm 0.11 \\
1.29 \\
14.8\end{array}$ & $\begin{array}{c}8.45 \pm 0.10 \\
1.23 \\
15.5\end{array}$ & $\begin{array}{c}8.87 \pm 1.36 \\
1.05 \\
11.3\end{array}$ & $\begin{array}{c}8.89 \pm 1.35 \\
0.93 \\
11.1\end{array}$ \\
\hline \multirow[t]{3}{*}{ Tap water } & 2.5 & $\begin{array}{c}2.02 \pm 0.02 \\
1.24 \\
19.2\end{array}$ & $\begin{array}{c}2.09 \pm 0.02 \\
1.20 \\
16.4\end{array}$ & $\begin{array}{c}2.15 \pm 1.34 \\
0.48 \\
14.0\end{array}$ & $\begin{array}{c}2.16 \pm 1.26 \\
0.83 \\
13.6\end{array}$ \\
\hline & 5.0 & $\begin{array}{c}4.27 \pm 0.06 \\
1.51 \\
14.6\end{array}$ & $\begin{array}{c}4.37 \pm 0.06 \\
1.44 \\
12.6\end{array}$ & $\begin{array}{c}4.35 \pm 1.42 \\
1.07 \\
13.0\end{array}$ & $\begin{array}{c}4.52 \pm 1.23 \\
0.61 \\
9.6\end{array}$ \\
\hline & 10.0 & $\begin{array}{c}8.22 \pm 0.12 \\
1.42 \\
17.8\end{array}$ & $\begin{array}{c}8.31 \pm 0.11 \\
1.56 \\
16.8\end{array}$ & $\begin{array}{c}8.67 \pm 1.35 \\
1.03 \\
13.3\end{array}$ & $\begin{array}{c}8.65 \pm 1.25 \\
0.93 \\
13.5\end{array}$ \\
\hline \multirow[t]{3}{*}{ River water } & 2.5 & $\begin{array}{c}2.03 \pm 1.34 \\
0.99 \\
18.8\end{array}$ & $\begin{array}{c}2.04 \pm 1.25 \\
0.98 \\
18.4\end{array}$ & $\begin{array}{c}2.12 \pm 1.20 \\
0.78 \\
15.2\end{array}$ & $\begin{array}{c}2.20 \pm 1.25 \\
0.80 \\
12.0\end{array}$ \\
\hline & 5.0 & $\begin{array}{c}4.62 \pm 1.28 \\
0.93 \\
7.6\end{array}$ & $\begin{array}{c}4.06 \pm 1.45 \\
0.98 \\
18.8\end{array}$ & $\begin{array}{c}4.38 \pm 1.29 \\
1.03 \\
12.4\end{array}$ & $\begin{array}{c}4.39 \pm 1.32 \\
0.94 \\
12.2\end{array}$ \\
\hline & 10.0 & $\begin{array}{c}8.12 \pm 1.42 \\
1.02 \\
18.8\end{array}$ & $\begin{array}{c}8.13 \pm 1.56 \\
1.18 \\
18.7\end{array}$ & $\begin{array}{c}8.64 \pm 1.44 \\
1.11 \\
13.6\end{array}$ & $\begin{array}{c}8.78 \pm 1.45 \\
0.98 \\
12.2\end{array}$ \\
\hline \multirow[t]{3}{*}{ Rain water } & 2.5 & $\begin{array}{c}2.05 \pm 1.20 \\
0.81 \\
18.0\end{array}$ & $\begin{array}{c}2.20 \pm 1.35 \\
0.98 \\
12.0\end{array}$ & $\begin{array}{c}2.08 \pm 1.26 \\
0.83 \\
16.8\end{array}$ & $\begin{array}{c}2.24 \pm 1.29 \\
1.02 \\
10.4\end{array}$ \\
\hline & 5.0 & $\begin{array}{c}4.22 \pm 1.34 \\
1.02 \\
15.6\end{array}$ & $\begin{array}{c}4.28 \pm 1.25 \\
0.93 \\
14.4\end{array}$ & $\begin{array}{c}4.35 \pm 1.35 \\
1.07 \\
13.0\end{array}$ & $\begin{array}{c}4.48 \pm 1.45 \\
1.39 \\
10.4\end{array}$ \\
\hline & 10.0 & $\begin{array}{c}8.54 \pm 1.33 \\
0.89 \\
14.6\end{array}$ & $\begin{array}{c}8.54 \pm 1.38 \\
0.97 \\
14.6\end{array}$ & $\begin{array}{c}8.62 \pm 1.53 \\
1.09 \\
13.8\end{array}$ & $\begin{array}{c}8.95 \pm 1.56 \\
1.17 \\
10.5\end{array}$ \\
\hline \multirow[t]{3}{*}{ Urine } & 2.5 & $\begin{array}{c}1.65 \pm 1.27 \\
0.80 \\
34.0\end{array}$ & $\begin{array}{c}1.72 \pm 1.26 \\
0.96 \\
31.2\end{array}$ & $\begin{array}{c}2.25 \pm 1.34 \\
1.02 \\
10.0\end{array}$ & $\begin{array}{c}2.37 \pm 1.28 \\
0.53 \\
5.2\end{array}$ \\
\hline & 5.0 & $\begin{array}{c}3.01 \pm 1.36 \\
0.99 \\
39.8\end{array}$ & $\begin{array}{c}3.10 \pm 1.24 \\
0.96 \\
38.0\end{array}$ & $\begin{array}{c}4.54 \pm 1.45 \\
1.09 \\
9.2\end{array}$ & $\begin{array}{c}4.60 \pm 1.41 \\
0.98 \\
8.0\end{array}$ \\
\hline & 10.0 & $\begin{array}{c}6.50 \pm 1.39 \\
0.92 \\
35.0\end{array}$ & $\begin{array}{c}6.60 \pm 1.33 \\
0.60 \\
34.0\end{array}$ & $\begin{array}{c}7.82 \pm 1.42 \\
1.10 \\
21.8\end{array}$ & $\begin{array}{c}7.81 \pm 1.35 \\
0.93 \\
21.9\end{array}$ \\
\hline \multirow[t]{3}{*}{ Medicine 1} & 2.5 & $\begin{array}{c}2.01 \pm 1.25 \\
0.99 \\
19.6\end{array}$ & $\begin{array}{c}2.07 \pm 1.35 \\
1.04 \\
17.2\end{array}$ & $\begin{array}{c}2.15 \pm 1.34 \\
0.48 \\
14.0\end{array}$ & $\begin{array}{c}2.20 \pm 1.26 \\
0.80 \\
12.0\end{array}$ \\
\hline & 5.0 & $\begin{array}{c}4.35 \pm 1.34 \\
1.07 \\
13.0\end{array}$ & $\begin{array}{c}4.37 \pm 1.41 \\
1.06 \\
12.6\end{array}$ & $\begin{array}{c}4.24 \pm 1.25 \\
0.95 \\
15.2\end{array}$ & $\begin{array}{c}4.41 \pm 1.56 \\
1.19 \\
11.8\end{array}$ \\
\hline & 10.0 & $\begin{array}{c}8.10 \pm 1.51 \\
1.07 \\
19.0\end{array}$ & $\begin{array}{c}8.40 \pm 1.62 \\
1.23 \\
16.0\end{array}$ & $\begin{array}{c}8.67 \pm 1.48 \\
1.15 \\
13.3\end{array}$ & $\begin{array}{c}8.75 \pm 1.60 \\
1.12 \\
12.5\end{array}$ \\
\hline
\end{tabular}


Table 4. Analytical precision and accuracy of C-DLLME and S-DLLME for Gal

\begin{tabular}{|c|c|c|c|c|c|}
\hline \multirow{2}{*}{ Sample code } & \multirow{2}{*}{$\begin{array}{l}\text { Added } \\
(\mu \mathrm{g} / \mathrm{L})\end{array}$} & \multicolumn{2}{|c|}{$\begin{array}{c}\text { C-DLLME } \\
\text { Found:mean } \pm \text { SD; RSD \%; RE \% }\end{array}$} & \multicolumn{2}{|c|}{$\begin{array}{c}\text { S-DLLME } \\
\text { Found:mean } \pm \text { SD; RSD \%; RE \% }\end{array}$} \\
\hline & & Inter day & Intra day & Inter day & Intra day \\
\hline \multirow[t]{3}{*}{ Mineral water } & 10.0 & $\begin{array}{c}8.67 \pm 1.42 \\
1.03 \\
13.3\end{array}$ & $\begin{array}{c}8.78 \pm 1.35 \\
0.98 \\
12.2\end{array}$ & $\begin{array}{c}9.23 \pm 1.34 \\
0.93 \\
7.7\end{array}$ & $\begin{array}{c}9.25 \pm 1.25 \\
0.97 \\
7.5\end{array}$ \\
\hline & 30.0 & $\begin{array}{c}26.26 \pm 1.52 \\
1.00 \\
12.4\end{array}$ & $\begin{array}{c}26.35 \pm 1.54 \\
1.12 \\
12.1\end{array}$ & $\begin{array}{c}27.72 \pm 1.48 \\
1.15 \\
7.6\end{array}$ & $\begin{array}{c}27.80 \pm 1.46 \\
1.07 \\
7.3\end{array}$ \\
\hline & 50.0 & $\begin{array}{c}44.12 \pm 1.55 \\
1.10 \\
11.7\end{array}$ & $\begin{array}{c}44.23 \pm 1.46 \\
1.10 \\
11.5\end{array}$ & $\begin{array}{c}45.84 \pm 1.45 \\
1.09 \\
8.3\end{array}$ & $\begin{array}{c}45.92 \pm 1.54 \\
1.18 \\
8.1\end{array}$ \\
\hline \multirow[t]{3}{*}{ Tap water } & 10.0 & $\begin{array}{c}8.82 \pm 1.21 \\
0.86 \\
11.8\end{array}$ & $\begin{array}{c}8.93 \pm 1.22 \\
0.95 \\
10.7\end{array}$ & $\begin{array}{c}9.10 \pm 1.26 \\
0.84 \\
9.0\end{array}$ & $\begin{array}{c}9.15 \pm 1.23 \\
0.94 \\
8.5\end{array}$ \\
\hline & 30.0 & $\begin{array}{c}26.72 \pm 1.63 \\
1.25 \\
10.9\end{array}$ & $\begin{array}{c}26.65 \pm 1.23 \\
0.91 \\
11.1\end{array}$ & $\begin{array}{c}27.35 \pm 1.42 \\
1.09 \\
8.8\end{array}$ & $\begin{array}{c}27.45 \pm 1.49 \\
1.06 \\
8.5\end{array}$ \\
\hline & 50.0 & $\begin{array}{c}45.43 \pm 1.44 \\
1.07 \\
11.1\end{array}$ & $\begin{array}{c}45.65 \pm 1.32 \\
1.01 \\
10.7\end{array}$ & $\begin{array}{c}44.75 \pm 1.55 \\
1.16 \\
10.5\end{array}$ & $\begin{array}{c}44.90 \pm 1.48 \\
1.14 \\
10.2\end{array}$ \\
\hline \multirow[t]{3}{*}{ River water } & 10.0 & $\begin{array}{c}8.03 \pm 1.23 \\
0.83 \\
19.7\end{array}$ & $\begin{array}{c}8.24 \pm 1.24 \\
0.44 \\
17.6\end{array}$ & $\begin{array}{c}9.10 \pm 1.36 \\
0.84 \\
9.0\end{array}$ & $\begin{array}{c}9.12 \pm 1.35 \\
1.05 \\
8.8\end{array}$ \\
\hline & 30.0 & $\begin{array}{c}24.10 \pm 1.35 \\
1.02 \\
19.6\end{array}$ & $\begin{array}{c}24.22 \pm 1.40 \\
1.10 \\
19.2\end{array}$ & $\begin{array}{c}27.15 \pm 1.42 \\
1.05 \\
9.5\end{array}$ & $\begin{array}{c}27.42 \pm 1.41 \\
1.06 \\
8.6\end{array}$ \\
\hline & 50.0 & $\begin{array}{c}39.65 \pm 1.25 \\
0.92 \\
20.7\end{array}$ & $\begin{array}{c}40.12 \pm 1.34 \\
0.96 \\
19.7\end{array}$ & $\begin{array}{c}44.6 \pm 1.58 \\
1.20 \\
10.8\end{array}$ & $\begin{array}{c}44.90 \pm 1.51 \\
1.14 \\
10.2\end{array}$ \\
\hline \multirow[t]{3}{*}{ Rain water } & 10.0 & $\begin{array}{c}8.75 \pm 1.38 \\
1.04 \\
12.5\end{array}$ & $\begin{array}{c}8.96 \pm 1.25 \\
0.93 \\
10.4\end{array}$ & $\begin{array}{c}9.01 \pm 1.32 \\
0.99 \\
9.9\end{array}$ & $\begin{array}{c}9.17 \pm 1.25 \\
0.98 \\
8.3\end{array}$ \\
\hline & 30.0 & $\begin{array}{c}26.16 \pm 1.25 \\
0.96 \\
12.8\end{array}$ & $\begin{array}{c}26.27 \pm 1.24 \\
0.93 \\
12.4\end{array}$ & $\begin{array}{c}27.10 \pm 1.25 \\
0.95 \\
9.6\end{array}$ & $\begin{array}{c}27.29 \pm 1.46 \\
1.12 \\
9.0\end{array}$ \\
\hline & 50.0 & $\begin{array}{c}43.54 \pm 1.41 \\
1.02 \\
12.9\end{array}$ & $\begin{array}{c}43.76 \pm 1.32 \\
0.99 \\
12.4\end{array}$ & $\begin{array}{c}43.95 \pm 1.48 ; 1.02 \\
12.1\end{array}$ & $\begin{array}{c}44.21 \pm 1.38 \\
1.04 ; \\
11.5\end{array}$ \\
\hline \multirow[t]{3}{*}{ Urine } & 10.0 & $\begin{array}{c}9.09 \pm 1.37 \\
0.95 \\
9.1\end{array}$ & $\begin{array}{c}9.11 \pm 1.27 \\
0.87 \\
8.9\end{array}$ & $\begin{array}{c}9.25 \pm 1.22 \\
0.97 \\
7.5\end{array}$ & $\begin{array}{c}9.31 \pm 1.35 \\
1.00 \\
6.9\end{array}$ \\
\hline & 30.0 & $\begin{array}{c}26.57 \pm 1.51 \\
1.09 \\
11.4\end{array}$ & $\begin{array}{c}26.80 \pm 1.48 \\
1.13 \\
10.6\end{array}$ & $\begin{array}{c}24.85 \pm 1.26 \\
0.87 \\
17.1\end{array}$ & $\begin{array}{c}25.00 \pm 1.44 \\
1.10 \\
16.6\end{array}$ \\
\hline & 50.0 & $\begin{array}{c}44.96 \pm 1.59 \\
1.22 \\
10.0\end{array}$ & $\begin{array}{c}45.21 \pm 1.59 \\
1.06 \\
9.5\end{array}$ & $\begin{array}{c}48.28 \pm 1.58 \\
1.11 \\
3.4\end{array}$ & $\begin{array}{c}48.51 \pm 1.43 \\
1.09 \\
2.9\end{array}$ \\
\hline \multirow[t]{3}{*}{ Medicine 2} & 10.0 & $\begin{array}{c}8.96 \pm 1.33 \\
0.89 \\
10.4\end{array}$ & $\begin{array}{c}9.01 \pm 1.30 \\
0.99 \\
9.9\end{array}$ & $\begin{array}{c}9.02 \pm 1.34 \\
0.88 \\
9.8\end{array}$ & $\begin{array}{c}9.08 \pm 1.42 \\
0.95 \\
9.2\end{array}$ \\
\hline & 30.0 & $\begin{array}{c}26.90 \pm 1.23 \\
0.87 \\
10.3\end{array}$ & $\begin{array}{c}26.92 \pm 1.34 \\
0.91 \\
10.2\end{array}$ & $\begin{array}{c}27.15 \pm 1.39 \\
0.58 \\
9.5\end{array}$ & $\begin{array}{c}27.22 \pm 1.53 \\
1.18 \\
9.2\end{array}$ \\
\hline & 50.0 & $\begin{array}{c}44.82 \pm 1.56 \\
1.22 \\
10.3\end{array}$ & $\begin{array}{c}45.01 \pm 1.52 \\
1.09 \\
9.9\end{array}$ & $\begin{array}{c}44.20 \pm 1.42 \\
1.06 \\
11.6\end{array}$ & $\begin{array}{c}44.66 \pm 1.56 \\
1.07 ; \\
10.6\end{array}$ \\
\hline
\end{tabular}




\subsection{Analysis of real samples}

Table 5. Relative performance of C-DLLME and S-DLLME in real samples

\begin{tabular}{|c|c|c|c|c|c|}
\hline \multirow[b]{3}{*}{ Type } & \multicolumn{2}{|l|}{ Sample } & \multicolumn{2}{|c|}{$\begin{array}{l}\text { Extraction recovery (ER \%), } \\
\text { Preconcentration factor }(\mathrm{PF})\end{array}$} & \\
\hline & \multirow{2}{*}{ Composition } & \multicolumn{2}{|c|}{ Mox } & \multicolumn{2}{|c|}{ Gal } \\
\hline & & C-DLLME & S-DLLME & C-DLLME & S-DLLME \\
\hline Tap water & $\begin{array}{l}\text { pH: 6.71; EC: } 625 \text {; Eh: 21.3; TDS: 400; F: } 0.86 \text {; } \\
\mathrm{Cl}^{-}: 251.22 ; \mathrm{NO}_{3}^{-}: 24.32 ; \mathrm{SO}_{4}^{2-}: 3.04 ; \mathrm{TH}: 92.50\end{array}$ & $\begin{array}{l}83.05, \\
24.08\end{array}$ & $\begin{array}{l}51.15 \\
51.15\end{array}$ & $\begin{array}{c}89.23 \\
9.81\end{array}$ & $\begin{array}{l}91.16, \\
53.78\end{array}$ \\
\hline Rain water & $\begin{array}{c}\text { pH: 6.49; EC: } 20.03 ; \mathrm{Eh}: 28.7 ; \mathrm{TDS}: 12.82 ; \mathrm{F}^{-}: 0.072 \\
\mathrm{Cl}^{-}: 0.1 ; \mathrm{NO}_{3}^{-}: 0.097 ; \mathrm{SO}_{4}^{2-}: 0.241 ; \mathrm{Na}^{+}: 0.097 \\
\mathrm{~K}^{+}: 0.027 ; \mathrm{Ca}^{2+}: 0.317 ; \mathrm{Mg}^{2+}: 0.070 ; \mathrm{HCO}_{3}^{-}: 0.06\end{array}$ & $\begin{array}{l}85.30 \\
24.73\end{array}$ & $\begin{array}{l}24.73 \\
53.10\end{array}$ & $\begin{array}{l}87.56 \\
9.63\end{array}$ & $\begin{array}{l}93.66, \\
55.25\end{array}$ \\
\hline River water & $\begin{array}{l}\text { pH: 6.78; EC: 608; Eh: } 25.0 \text {; TDS: } 389.12 ; \text { DO: } 7.01 ; \\
\text { TH: } 102.4 ; \mathrm{PO}_{4}{ }^{3-}: 0.098 ; \mathrm{NO}_{3}{ }^{-}: 0.032\end{array}$ & $\begin{array}{l}81.20 \\
23.54\end{array}$ & $\begin{array}{l}86.40 \\
50.97\end{array}$ & $\begin{array}{c}80.34 \\
8.84\end{array}$ & $\begin{array}{l}89.20 \\
52.62\end{array}$ \\
\hline Urine & $\begin{array}{c}\text { pH: } 6.57 ; \mathrm{EC}: 19.14 ; \mathrm{Eh}: 29.6 ; \mathrm{TDS}: 12.24 ; \text { Urea: } 9.3 \text {; } \\
\mathrm{Cl}: 1.87 ; \mathrm{Na}^{+}: 1.17 ; \mathrm{K}^{+}: 0.750 ; \text { Creatinine: } 0.670 ; \\
\text { Inorganic sulfur: } 0.163\end{array}$ & $\begin{array}{l}62.32 \\
18.07\end{array}$ & $\begin{array}{l}78.20 \\
46.13\end{array}$ & $\begin{array}{c}70.90 \\
9.99\end{array}$ & $\begin{array}{l}96.20 \\
56.75\end{array}$ \\
\hline Medicine 1 & $\begin{array}{l}\text { Nature: Liquid for intravenous administration; } \\
\text { Each } 100 \mathrm{~mL} \text { contains: Moxifloxacin: } 400 \mathrm{mg} \text {, } \\
\text { Mannitol: } 5 \mathrm{~g}\end{array}$ & $\begin{array}{l}82.37 \\
23.88\end{array}$ & $\begin{array}{l}87.51 \\
51.62\end{array}$ & & \\
\hline Medicine 2 & $\begin{array}{l}\text { Nature: Solid as tablet; } \\
\text { Galantamine: } 4 \text { mg } \\
\text { Titanium dioxide (color) }\end{array}$ & & & $\begin{array}{l}89.61 \\
9.85\end{array}$ & $\begin{array}{l}90.25 \\
53.24\end{array}$ \\
\hline
\end{tabular}

All except pH, EC ( $\mu \mathrm{S} / \mathrm{m})$, Eh $(\mathrm{mV})$ in $\mathrm{mg} / \mathrm{L}$

Table 6. Comparison with reported methods

\begin{tabular}{|c|c|c|c|c|c|}
\hline Method & Sample origin & $\begin{array}{l}\text { Vol. of ES } \\
\quad(\mu \mathrm{L})\end{array}$ & ER \% & $\mathrm{PF}$ & Reference \\
\hline \multicolumn{6}{|c|}{ Galantamine } \\
\hline $\begin{array}{l}\text { Ionic liquid-supported solid-liquid } \\
\text { extraction using HPLC-UV }\end{array}$ & Plant & $12 \#$ & $97.86-100.86$ & - & 31 \\
\hline $\begin{array}{l}\text { Solid-phase extraction and reversed-phase high performance } \\
\text { liquid chromatography diode array detector }\end{array}$ & Plant & - & 91.3 & - & 32 \\
\hline $\begin{array}{l}\text { High-performance liquid chromatographic method with } \\
\text { UV photodiode-array, fluorescence and mass } \\
\text { spectrometric detection }\end{array}$ & Bio & - & 81.0 & - & 35 \\
\hline \multirow[t]{2}{*}{$\begin{array}{l}\text { DLLME coupled with HPLC-UV } \\
\text { Conventional/SDS assisted }\end{array}$} & $\begin{array}{l}\text { Water, urine and } \\
\text { medical formulations }\end{array}$ & $500 / 100$ & $86.88 / 92.00$ & $10.94 / 46.92$ & $\begin{array}{l}\text { Present } \\
\text { report }\end{array}$ \\
\hline & Moxifloxacin & & & & \\
\hline $\begin{array}{l}\text { Dispersive liquid-liquid microextraction combined with } \\
\text { ultra-high performance liquid chromatography }\end{array}$ & Mineral, runoff water & 658 & $94.00,111.00$ & - & 33 \\
\hline $\begin{array}{l}\text { Solid phase microextraction fibers and } \\
\text { liquid-chromatography-tandem mass spectrometry }\end{array}$ & Whole blood & - & 99.29 & - & 34 \\
\hline $\begin{array}{l}\text { Solid phase extraction combined with } \\
\text { liquid chromatography }\end{array}$ & $\begin{array}{l}\text { Dilatation and curettage } \\
\text { material }\end{array}$ & - & 92.70 & - & 36 \\
\hline $\begin{array}{l}\text { DLLME coupled with HPLC-UV } \\
\text { Conventional/SDS assisted }\end{array}$ & $\begin{array}{l}\text { Water, urine and } \\
\text { medical formulations }\end{array}$ & $200 / 100$ & $85.03 / 89.56$ & $26.35 / 45.39$ & $\begin{array}{l}\text { Present } \\
\text { report }\end{array}$ \\
\hline
\end{tabular}


Tap water was collected from Kalyani University tap, rainwater was collected in the rainy season and river water from the Hooghly river (22049’ N, 88020’ E; West Bengal, India). Urine samples used were collected from healthy young male adults without any medication. Initially, samples were found free from the contamination of the drugs. The samples were spiked with the desired level of standard drug solution prior to extraction. Table 5 indicates the efficiency of C-DLLME and S-DLLME in real samples in terms of ER \% and PF. The data reveals that both ER \% and PF increase in S-DLLME compared to C-DLLME. Although both C-DLLME and S-DLLME are effective, considering the low volume of ES, without any requirement of DS, higher ER \% and PF as well as greater thermodynamic feasibility the S-DLLME is highly recommended for the extraction of pharmaceuticals from water and bio-samples. Finally, the present method is compared with the reported methods (Table 6).

(a)

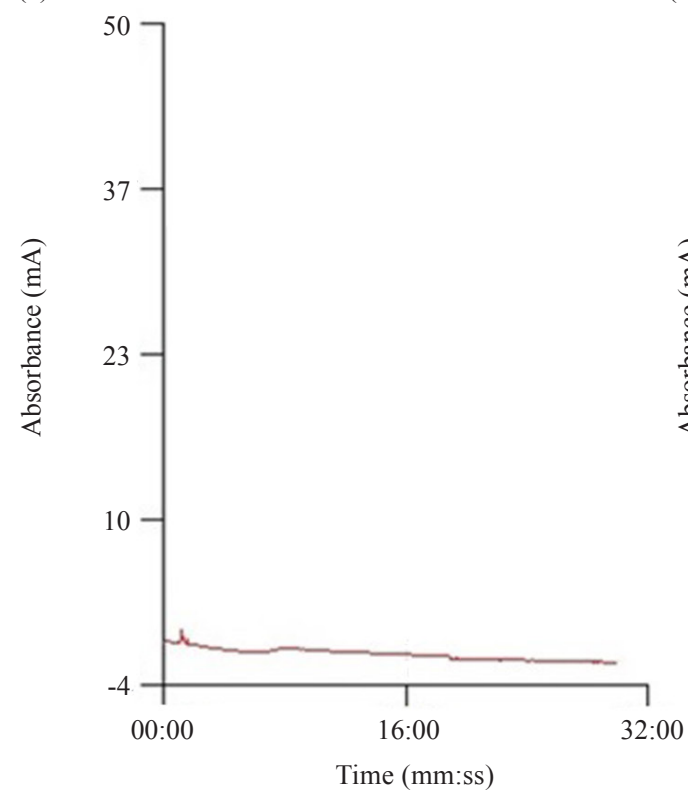

(c)

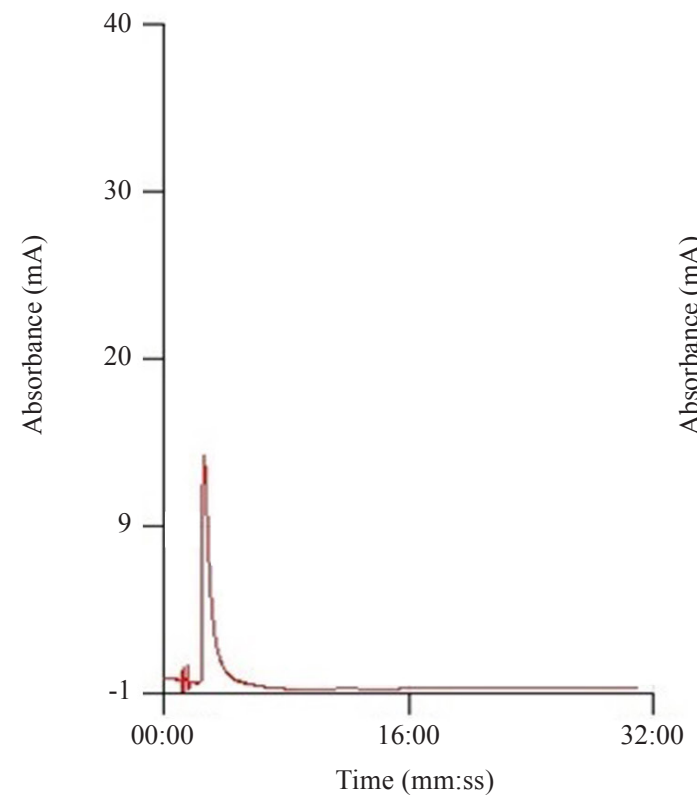

(b)

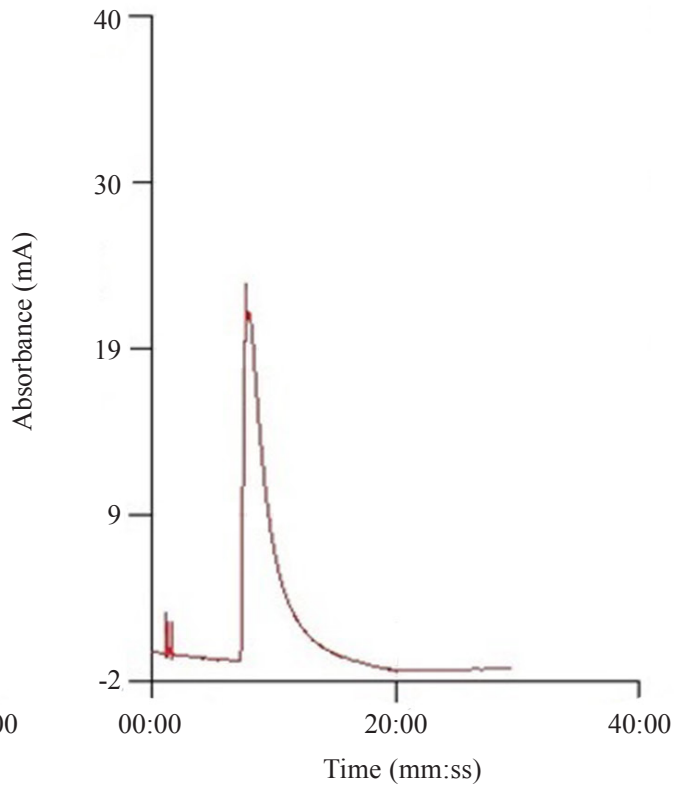

(d)

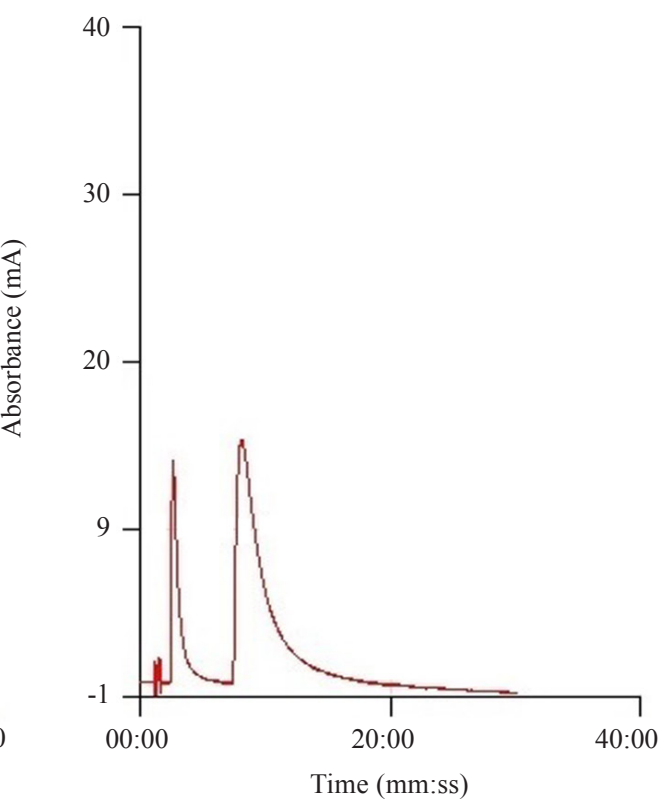

Figure 14. Chromatogram of (a) M-phase, (b) Mox-M-phase, (c) Gal-M-phase, (d) Mox-Gal-M-phase Experimental condition: M-phase, $\left(\mathrm{NH}_{4}\right) \mathrm{H}_{2} \mathrm{PO}_{4}: \mathrm{CH}_{3} \mathrm{CN}$ : 70:30, adjusted at $\mathrm{pH} 3$ by ortho- $\mathrm{H}_{3} \mathrm{PO}_{4}$; Flow rate, $1 \mathrm{~mL} / \mathrm{min}$; spiked samples concentration, Mox: $2.5 \mu \mathrm{g} / \mathrm{L}$ and Gal: $10 \mu \mathrm{g} / \mathrm{L}$ 
Further, the HPLC analyses of the samples were performed to identify and quantify each drug in the samples. The chromatograms of some representative samples were presented in Figure 14-16 (Figure 14, blank; and spiked: Figure 15, tap water; Figure 16: urine). The peak retention time parameter was matched with the standard, to identify the respective drug. Some additional peaks in tap water and urine sample indicated the matrix effect. The quantification of the peak area indicated the drug concentration in the sample.
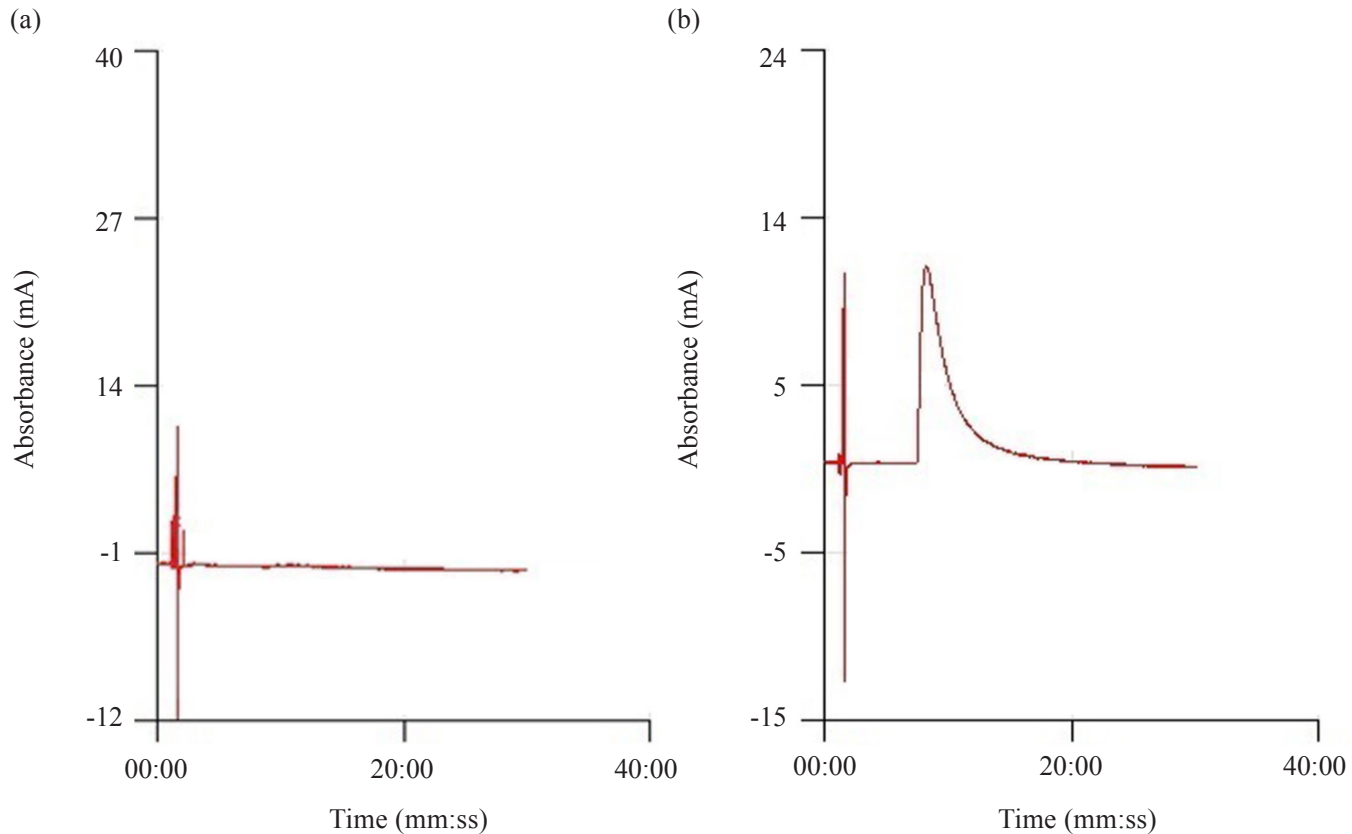

(c)

(d)
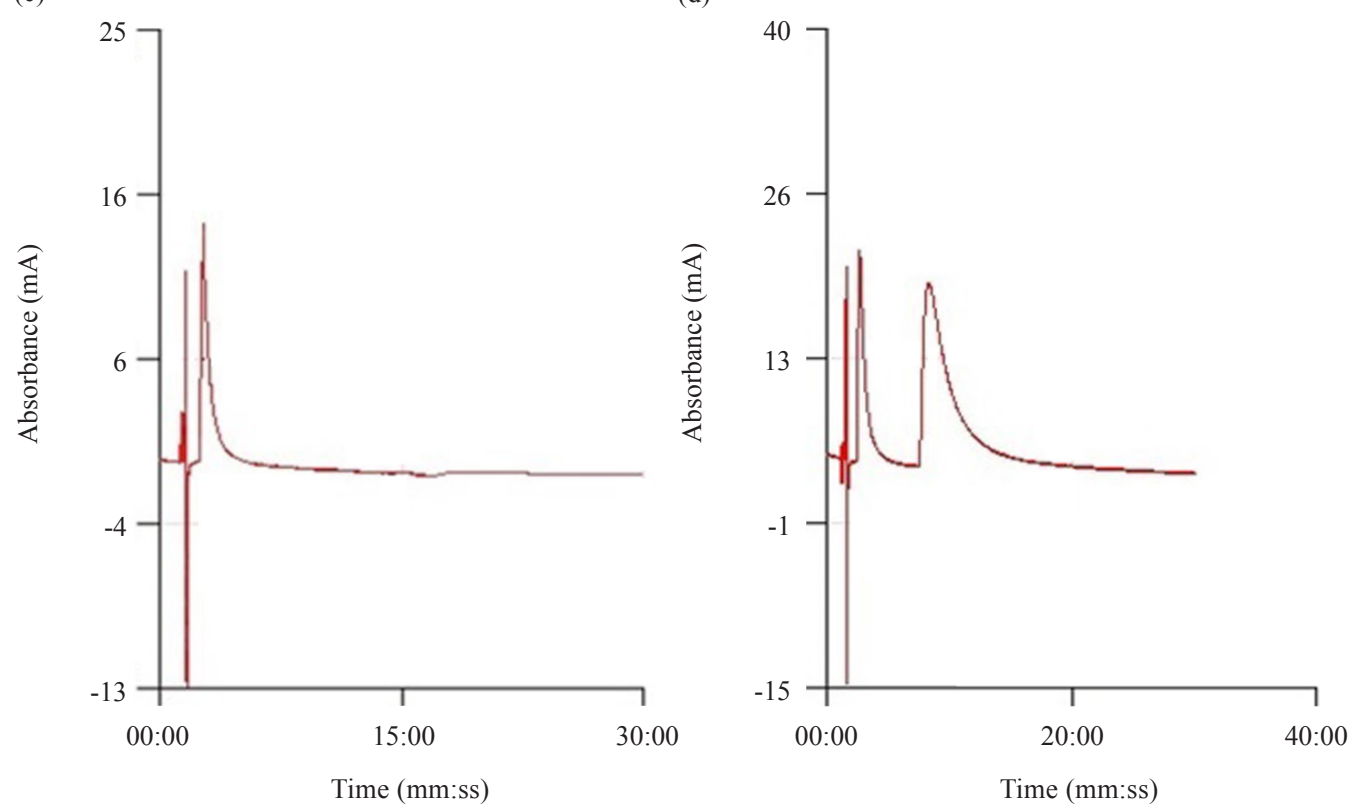

Figure 15. Chromatogram of (a) tap water, (b) Mox-tap water, (c) Gal-tap water, (d) Mox-Gal-tap water Experimental condition: same as that in Figure 14 

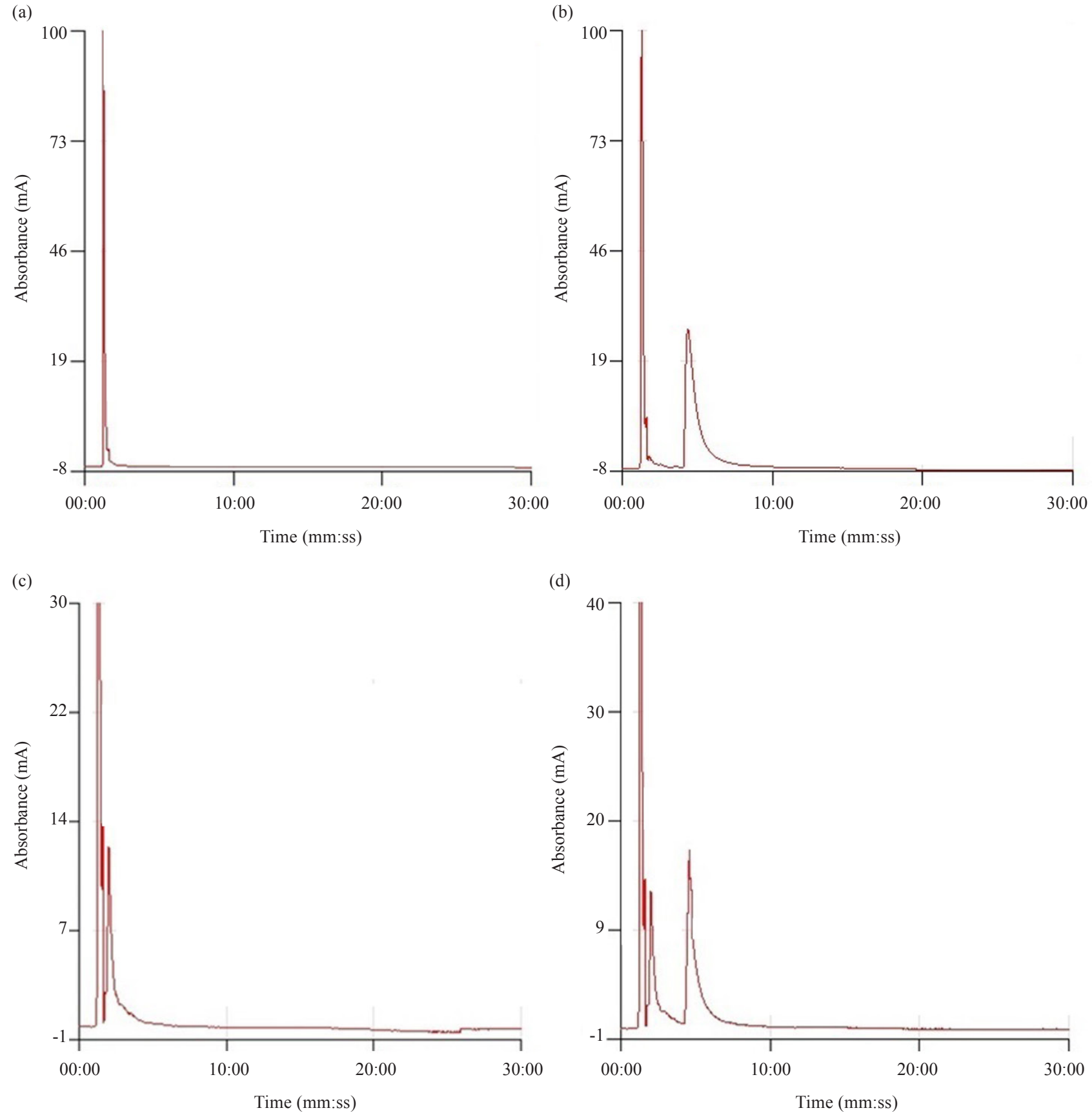

Figure 16. Chromatogram of (a) urine, (b) Mox-urine, (c) Gal-urine, (d) Mox-Gal-urine Experimental condition: same as that in Figure 14

\section{Conclusions}

Extractive recovery prior to determination of pharmaceuticals, viz. moxifloxacin and galantamine, was developed using C-DLLME coupled with HPLC-UV. The optimized condition was found to be ES1-DS1 at pH 6.9 and 5 min for Mox, and ES2-DS1 at pH 10.2 and 5 min for Gal. The method is simple, sensitive, rapid, cost-effective, the linear range of determination, thermodynamically feasible. An improved operation in terms of efficiency, preconcentration factor, spontaneity, and greenness is achieved in S-DLLME using ES1 and SDS (> CMC). The low volume requirement of ES, no use DS, and no need for $\mathrm{pH}$ adjustment make the process more promising. Similar extraction of the drugs can 
be achieved with SDS ( $<\mathrm{CMC})$, but with some higher volume. Temperature plays an insignificant role in improving extraction efficiency. The addition of some common ion to the sample solution was found to somewhat enhance the extraction efficiency of Mox, although much less than that of C-DLLME at the optimized condition and S-DLLME. The method can be applied for the analysis of different water and urine samples as well as in medical formulations. The method may be used for assessing the active component as well as to detect spurious medicines.

\section{Acknowledgements}

The authors sincerely acknowledge the facilities received under UGC-SAP, DST-FIST, and DST-PURSE, Govt of India. One of the authors (SD) is thankful to UGC for providing the research fellowship.

\section{Conflict of interest}

The authors declare that there is no conflict of interest.

\section{References}

[1] Hernando, M. D.; Mezcua, M.; Fernandez-Alba, A. R.; Barcelo, D. Environmental risk assessment of pharmaceutical residues in wastewater effluents, surface waters and sediments. Talanta 2006, 69, 334-342.

[2] Raikos, N.; Spagou, K.; Vlachou, M.; Pouliopoulos, A. Development of a liquid-liquid extraction procedure for the analysis of amphetamine in biological specimens by GC-FID. The Open Forensic Sci. J. 2009, 2, 12-15.

[3] Remane, D.; Meyer, M. R.; Peters, F. T.; Wissenbach, D. K.; Maurer, H. H. Fast and simple procedure for liquidliquid extraction of 136 analytes from different drug classes for development of a liquid chromatographic-tandem mass spectrometric quantification method in human blood plasma. Anal. Bioanal. Chem. 2010, 397, $2303-2314$.

[4] Lindberg, R.; Jarnheimer, P. A.; Olsen, B.; Johansson, M.; Tysklind, M. Determination of antibiotic substances in hospital sewage water using solid phase extraction and liquid chromatography/mass spectrometry and group analogue internal standards. Chemosphere 2004, 57, 1479-1488.

[5] Zhou, J. L.; Maskaoui, K.; Lufadeju, A. Optimization of antibiotic analysis in water by solid-phase extraction and high performance liquid chromatography-mass spectrometry/mass spectrometry. Anal. Chim. Acta. 2012, 731, 3239.

[6] Dzomba, P.; Kugara, J.; Zaranyika, M. F. Extraction of tetracycline antimicrobials from river water and sediment: a comparative study of three solid phase extraction methods. African J. Pharm. Pharma. 2015, 9, 523-531.

[7] Schubert, J. K.; Miekisch, W.; Fuchs, P.; Scherzer, N.; Lord, H.; Pawliszyn, J.; Mundkowski, R. G. Determination of antibiotic drug concentrations in circulating human blood by means of solid phase micro-extraction. Clin. Chim. Acta. 2007, 386, 57-62.

[8] Szultka, M.; Szeliga, J.; Jackowski, M.; Buszewski, B. Development of novel molecularly imprinted solid-phase microextraction fibers and their application for the determination of antibiotic drugs in biological samples by SPME-LC/MS ${ }^{\mathrm{n}}$. Anal. Bioanal. Chem. 2012, 403, 785-796.

[9] Kukusamudea, C.; Santalad, A.; Boonchiangm, S.; Burakhama, R.; Srijaranai, S.; Chailapakul, O. Mixed micelle-cloud point extraction for the analysis of penicillin residues in bovine milk by high performance liquid chromatography. Talanta 2010, 81, 486-492.

[10] Khammas, A-A. Z.; Mubdir, N. S. An eco-friendly method for extraction and determination of ciprofloxacin in blood serum and pharmaceuticals. Sci. J. Anal. Chem. 2014, 2, 47-54.

[11] Gardner, M. A.; Sampsel, S.; Jenkins, W. W.; Owens, J. E. Analysis of fentanyl in urine by DLLME-GC-MS. J. Anal. Toxicol. 2015, 39, 118-125.

[12] Habibollahi, S.; Tavakkoli, N.; Nasirian, V.; Khani, H. Determination of tramadol by dispersive liquid-liquid microextraction combined with GC-MS. J. Chromatogr. Sci. 2015, 53, 655-661.

[13] Osboo, R. K. Miri, R.; Javidnia, K.; Kobarfard, F. Simultaneous chloramphenicol and florfenicol determination by a validated DLLME-HPLC-UV method in pasteurized milk. Iranian J. Pharma. Res. 2016, 15, 361-368.

[14] Lai, G.; Chen, G.; Chen, T.; Li, Q. Rapid screening of oxytetracycline residue in fish muscle by dispersive liquid- 
liquid microextraction and europium-sensitized luminescence. Food Anal. Methods 2015, 8, 2052-2058.

[15] Hou, D.; Guan, Y.; Di, X. Temperature-induced ionic liquids dispersive liquid-liquid microextraction of tetracycline antibiotics in environmental water samples assisted by complexation. Chromatographia 2011, 73, 1057-1060.

[16] Chen, K. Y.; Yang, T. C.; Chang, S. Y. Determination of macrolide antibiotics using dispersive liquid-liquid microextraction followed by surface-assisted laser desorption/ionization mass spectrometry. J. Am. Soc. Mass Spectrom. 2012, 23, 1157-1160.

[17] Parrilla, V. M. M.; Parrilla, V. P.; Martínez, G. M.; Gil, G. M. D. Determination of eight fluoroquinolones in groundwater samples with ultrasound-assisted ionic liquid dispersive liquid-liquid microextraction prior to highperformance liquid chromatography and fluorescence detection. Anal. Chim. Acta. 2012, 748, 20-27.

[18] Huang, P.; Zhao, P.; Dai, X.; Hou, X.; Zhao, L.; Liang, N. Trace determination of antibacterial pharmaceuticals in fishes by microwave-assisted extraction and solid-phase purification combined with dispersive liquid-liquid microextraction followed by ultra-high performance liquid chromatography-tandem mass spectrometry. $J$. Chromatogr. B 2016, 1011, 136-144.

[19] Gao, W.; Chen, G.; Chen, Y.; Zhang, X.; Yin, Y.; Hu, Z. Application of single drop liquid-liquid-liquid microextraction for the determination of fluoroquinolones in human urine by capillary electrophoresis. $J$. Chromatogr. B 2011, 879, 291-295.

[20] Karami-Osboo, R.; Shojaee, M. H.; Miri, R.; Kobarfard, F.; Javidnia, K. Simultaneous determination of six fluoroquinolones in milk by validated QuEChERS-DLLME HPLC-FLD. Anal. Methods 2014, 6, 5632-5638.

[21] Herrera-Herrera, A. V.; Hernández-Borges, J.; Borges-Miquel, T. M.; Rodríguez-Delgado, M. A. Dispersive liquid-liquid microextraction combined with nonaqueous capillary electrophoresis for the determination of fluoroquinolone antibiotics in waters. Electrophoresis 2010, 31, 3457-3465.

[22] Suna, X.; Xinga, X.; Dua, Z. Application of dispersive liquid-liquid microextraction based on solidification of floating organic drop for the determination of extractables from pharmaceutical packaging materials. Talanta 2020, 209, 120540.

[23] Xiong, C.; Ruan, J.; Cai, Y.; Tang, Y. Extraction and determination of some psychotropic drugs in urine samples using dispersive liquid-liquid microextraction followed by high-performance liquid chromatography. J. Pharm. Biomed. Anal. 2009, 49, 572-578.

[24] Shamsipur, M.; Mirmohammad, M. High performance liquid chromatographic determination of ultratraces of two tricyclic antidepressant drugs imipramine and trimipramine in urine samples after their dispersive liquid-liquid microextraction coupled with response surface optimization. J. Pharm. Biomed. Anal. 2014, 100, 271-278.

[25] Andruch, V.; Kocurova, L.; Balogh, I. S.; Skrlikova, J. Recent advances in coupling single-drop and dispersive liquid-liquid microextraction with UV-vis spectrophotometry and related detection techniques. Microchem. J. 2012, 102, 1-10.

[26] Syaleyana, D.; Md Shukri, M.; Sanagi, M. M.; Wan, A. W.; Wan, I. W.; Nurul, N. N.; Zainal, A. Z.; Aboul, E. H. Y. Chromatographic determination of NSAIDs in urine after dispersive liquid-liquid microextraction based on solidification of floating organic droplets. Chromatographia 2015, 78, 987-994.

[27] Yi, X.; Bayen, S.; Kelly, B. C.; Xu, L.; Zhi, Z. Improved detection of multiple environmental antibiotics through an optimized sample extraction strategy in liquid chromatography-mass spectrometry analysis. Anal. Bioanal. Chem. 2015, 407, 9071-9083.

[28] Bayrak, Y. Micelle formation in sodium dodecyl sulfate and dodecyltrimethylammonium bromide at different temperatures. Turk. J. Chem. 2003, 27, 487-492.

[29] Moradi, M.; Yamini, Y.; Esrafili, A.; Seidi, A. Application of surfactant assisted dispersive liquid-liquid microextraction for sample preparation of chlorophenols in water samples, Talanta 2010, 82, 1864-1869.

[30] Vera-Avila, L. E.; Rojo-Portillo, T.; Covarrubias-Herrera, R.; Pena-Alvarez, A. Capabilities and limitations of dispersive liquid-liquid microextraction with solidification of floating organic drop for the extraction of organic pollutants from water samples. Anal. Chim. Acta. 2013, 805, 60-69.

[31] Svinyarov, I.; Keremedchieva, R.; Bogdanov, M. G. Ionic liquid-supported solid-liquid extraction of bioactive alkaloids. IV. new HPLC method for quantitative determination of galantamine in Leucojum aestivum L (Amaryllidaceae). Sep. Sci. and Tech. 2016, 51, 15-16.

[32] Lopez, S.; Bastida, J.; Viladomat, F.; Codina, C. Solid-phase extraction and reversed-phase high-performance liquid chromatography of the five major alkaloids in narcissus confuses. Phytochem. Anal. 2002, 13, 311-315.

[33] Herrera-Herrera, A. V.; Hernandez-Borges, J.; Borges-Miquel, T. M.; Rodriguez-Delgado, M. A. Dispersive liquid-liquid microextraction combined with ultra-high performance liquid chromatography for the simultaneous determination of 25 sulfonamide and quinolone antibiotics in water samples. J. Pharm. Biomed. Anal. 2013, 75, 
130-137.

[34] Szultka, M.; Krzeminski, R.; Jackowski, M.; Buszewskia, B. Simultaneous determination of selected chemotherapeutics in human whole blood by molecularly imprinted polymers coated solid phase microextraction fibers and liquid chromatography-tandem mass spectrometry. J. Chromatogr. B 2013, 940, 66-76.

[35] Malakova, J.; Nobilis, M.; Svoboda, Z.; L1sa, M.; Holcapek, M.; Kvetina, J.; Klimes, J.; Palicka, V. Highperformance liquid chromatographic method with UV photodiode-array, fluorescence and mass spectrometric detection for simultaneous determination of galantamine and its phase I metabolites in biological samples. $J$. Chromatogr. B 2007, 853, 265-274.

[36] Nemutlu, E.; Katlan, D.; Ozyuncu O.; Kır, S.; Beksac, M. S. Quantification of moxifloxacin and levofloxacin in curettage material by SPE-LC. Chromatographia 2010, 71, 1147-1150. 